\title{
Race, Gender, and Parental College Savings: Assessing Economic and Academic Factors ${ }^{1}$
}

\author{
Natasha Quadlin \\ Assistant Professor \\ University of California, Los Angeles \\ Jordan A. Conwell \\ Assistant Professor \\ University of Wisconsin-Madison
}

Forthcoming, Sociology of Education

(Near-final manuscript; April 22, 2020 version)

Citation:

Quadlin, Natasha and Jordan A. Conwell. Forthcoming. "Race, Gender, and Parental College Savings: Assessing Economic and Academic Factors.” Sociology of Education.

${ }^{1}$ We are grateful to Brian Powell and Rachel Dwyer for comments on a previous version of this article. Direct correspondence to Natasha Quadlin, 264 Haines Hall, 375 Portola Plaza, Los Angeles, CA 90095, USA. 


\section{Race, Gender, and Parental College Savings: \\ Assessing Economic and Academic Factors}

This article assesses the relationships between race, gender, and parental college savings. Although some prior studies have investigated race differences in parental college savings, none have taken an intersectional approach, and most of these studies were conducted with cohorts of students who pre-date key demographic changes among U.S. college-goers (such as the reversal of the gender gap in college completion). Drawing on theories of parental investment and data from the High School Longitudinal Study of 2009 (HSLS:09), we show that both race and gender are associated with whether parents save for college, as well as how much they save. Both Black boys and Black girls experience savings disadvantages relative to their White peers. However, particularly striking disparities face Black girls: Black girls with the strongest academic credentials receive savings equivalent to those with the weakest academic credentials. Results suggest that this in due, at least in part, to the fact that high-achieving Black girls tend to come from families that are much less well-off than high achievers in other race-gender groups. As a result, parents of Black girls frequently rely on funding sources other than their own earnings or savings to pay for their children's college. These include private loans that may pose financial challenges for Black girls and their families across generations, thus deepening inequalities along the lines of gender, race, and class. These findings demonstrate the power of taking an intersectional approach to the study of higher education in general and college funding in particular.

Keywords: savings for college/education, gender, race, higher education 
Paying for college is harder than it used to be. As tuition and fees have increased at universities across the country, students and their parents have made much greater sacrifices to pay for higher education (Dwyer 2018; Dwyer, McCloud, and Hodson 2012; Houle 2014a, 2014b; Houle and Warner 2017). As of 2018, Americans have amassed \$1.5 trillion in student loans, surpassing credit cards and auto loans to become the second-highest debt category, behind only mortgages (Federal Reserve Bank of New York 2018). Although rising college costs have affected all college students, data suggest that students of color — and especially Black students - have been disproportionately impacted. Compared to their White peers, Black students have higher debt balances, higher interest rates, and are more likely to default on their loans (Houle and Addo 2019; Jackson and Reynolds 2013; Scott-Clayton and Li 2016).

Social scientists have investigated many causes of Black-White differences in college funding and outcomes, such as race differences in the type and quality of post-secondary institutions attended (Carnevale and Strohl 2013; Iloh and Toldson 2013). In this article, we assess one factor that has received comparatively less attention, especially since the beginning of the student debt crisis: parental college savings. In many ways, parental college savings is a product of historical and contemporary racial disadvantages that have already played a role in shaping families' finances by the time their children begin to think about college. Parents' ability to save for their children's college education is a product of many factors, including not only income but also wealth, which differs substantially by race and compounds across generations (Addo, Houle, and Simon 2016; Darity et al. 2018; Herring and Henderson 2016).

Aside from race, gender is a key factor that may shape parental college savings. Girls have better academic performance than boys throughout the K-12 years, and women are more likely than men to earn bachelor's degrees (Buchmann and DiPrete 2006). White women's rates 
of B.A. completion surpassed White men's beginning with cohorts born after 1960, and Black women have outpaced Black men in this regard since as early as the 1930 birth cohorts (DiPrete and Buchmann 2013). At the same time, theories of parental investment suggest that parents might invest more resources in boys' education, given that social and economic opportunity structures continue to advantage men (Raley and Bianchi 2006). This evidence suggests that parental college savings is likely to vary by gender - whether due to parents' beliefs about their children's abilities, or broader attitudes toward gender socialization.

In this article, we take a quantitative, intersectional approach to the study of parental college savings. Drawing on the perspective that race and gender have multiplicative effects on numerous dimensions of life chances (Collins 1990; Crenshaw 1989, 1991; McCall 2005; Wingfield 2009), we contend that both race and gender are likely to affect whether parents save for their children's college education, as well as how much they save. We use theories of parental investment to make this argument, as well as empirical findings that point to persistent race and gender differences in how students pay for college. To investigate these dynamics, we use data from the High School Longitudinal Study of 2009 (HSLS:09), a survey conducted by the National Center for Education Statistics (NCES). The HSLS is the most recent nationally representative survey with rich data on parental college savings and pre-college social and academic experiences, making it an ideal dataset for our study. In addition to the main analyses that assess parental college savings among $11^{\text {th }}$ graders, we also examine the other funding sources that parents anticipate using to pay for college. Depending on whether these funding sources must be repaid — not to mention their interest rates, repayment schedules, and who is responsible for repaying them - these anticipated funding sources can have long-term implications for financial well-being across race-gender groups. In total, our findings reiterate 
the idea that college funding is a mechanism through which higher education reproduces inequality. We show that these inequalities emerge at the nexus of race, gender, and pre-college achievement - a combination of factors that has been under-examined in the literature on funding for higher education.

\section{RACE, GENDER, AND PARENTAL COLLEGE SAVINGS}

Although research on college funding remains nascent, several recent studies have considered how students pay for college (Dwyer et al. 2012; Hamilton 2013; Quadlin 2017; Quadlin and Rudel 2015), and how these funding arrangements differ by race (McCabe and Jackson 2016). Most of this research focuses on student loan debt — and rightly so, given that racial differences in student loans are large and have persistent effects throughout the life course. Black college students accrue substantially more educational debt than White students (Addo et al. 2016). Although these gaps in student loans emerge during college, they continue to grow after students leave, as Black students face more barriers in making loan payments (such as discrimination in the labor market, which contributes to lesser returns to educational attainment), and their loans carry higher interest rates than that of their White peers (Scott-Clayton and Li 2016). We therefore focus on Black-White comparisons in this article, as have many other scholars, but other racial groups (such as Latinx, Asian, and Native American youth) warrant investigation in future work.

Less research has focused on gender differences in borrowing, but recent estimates indicate that women graduate with more debt than men. The average woman graduates with about $\$ 21,000$ in student loans, versus about $\$ 19,500$ for men (Miller 2019). There is also evidence that men and women respond to debt differently. Both men and women have diminished chances of graduating when they have high debt balances, but men tend to drop out 
at lower debt levels than women, suggesting that women have a higher tolerance for indebtedness (Dwyer, Hodson, and McCloud 2013).

Despite this growing emphasis on student loan debt in the social science literature, relatively little research has considered the issue of parental college savings (but see Turley and Desmond 2011). Even less research has focused on race and gender differences in parental college savings - and we are aware of no research that takes an intersectional approach to this topic. In some ways, this scholarly focus on debt rather than parental savings is justified, given that disparities in parental savings frequently morph into disparities in student loan debt as students seek to cover their unmet financial need (Rauscher 2016). Yet, saving for college is a distinct social process that is shaped not only by parents' ability to pay for college (itself a product of intergenerational processes influenced by structural racial inequality), but also parents' forecasting of their children's academic potential for college, as discussed in detail in the next section. Research on parental college savings, therefore, provides additional insight into family decision-making and historical and contemporary racial inequality and that is related to, but distinct from, the issue of student loans.

A handful of studies have considered racial differences in parental college savings using data on earlier cohorts of students. Steelman and Powell (1993) use data from High School and Beyond and NELS:88 to show that Black parents invest just as much (if not more) in college than White parents once background characteristics are controlled for. Others have similarly used NELS:88 data to show that Black-White differences in social class account for racial gaps in parental savings and, in turn, college attendance (Charles, Roscigno, and Torres 2007). These studies provide key insight into race and parental college savings, but the data used in these analyses are now more than 30 years old. Many demographic changes have occurred in the 
intervening period — including, but not limited to, the reversal of the gender gap in college completion among Whites (which was only beginning to emerge in the 1980s), and Black women continuing to grow their advantage in college completion over Black men (DiPrete and Buchmann 2013). This warrants an updated investigation into parental college savings that emphasizes both race and gender.

\section{ASSESSING ECONOMIC AND ACADEMIC FACTORS}

Drawing on theories of parental investment and prior empirical findings, we contend that two main sets of factors are responsible for shaping patterns of parental college savings in the United States. The first is economic and family factors, which encompass opportunities and constraints that affect parents' ability to save for their children's college education. The second is academic factors, which reflect the student's academic preparation for college. Parents may use these academic indicators to make an educated guess about their children's likelihood of attending college, which, in turn, may affect parents' tendency to save. Below, we outline these two sets of factors and discuss how they may vary by both race and gender (i.e., in an intersectional manner) in shaping parental savings for college.

\section{Economic/Family Factors and Parental College Savings}

Generally speaking, parents in higher socioeconomic status (SES) groups provide children with more college funding than those in lower SES groups. Of course, there are some exceptions to this rule, such as affluent parents who would prefer their children work their way through college in order to have some "skin in the game" (Hamilton 2016). However, research typically observes a positive relationship between parental SES and their spending on children's college education (Hamilton 2013; Quadlin 2017; Turley and Desmond 2011). Studies suggest also that family configuration plays a role when it comes to children's receipt of economic 
resources for college. According to resource dilution theories of parental investment, as the number of children in a family increases, the amount of parental investment that can be provided to any one child decreases (Downey 1995; Gibbs, Workman, and Downey 2016; Steelman et al. 2002). Higher education is especially prone to resource dilution because it is so challenging for parents to pay for multiple children (or even one child, for that matter) to attend college. Gender composition of sibship also matters: some research shows that children's resources for college are most diluted when they have multiple brothers (but not sisters), presumably because parents are more motivated to provide college funding for sons than daughters (Powell and Steelman 1989).

Although both race and gender are linked to constraints on parental college savings, race typically is considered a more salient factor because race is strongly linked with economic status. A long line of research shows that Black families are disadvantaged relative to White families across multiple economic indicators, including income, wealth, and educational attainment. These disparities are a reflection of historical and contemporary processes of racism and discrimination in the labor market, housing, access to credit, and other linked institutions (Wilson 1978, 2011, 2012). There is also evidence to suggest that racial differences in parental college savings vary across the economic spectrum. For example, research shows that BlackWhite differences in student loan debt are largest at the highest levels of parental wealth, in part because high-wealth White families have exponentially more assets than their Black counterparts (Addo et al. 2016). This pattern implies that we would also observe a racial gap in parental college savings among the most advantaged families.

By comparison, less research has focused on race differences in parental college savings among the least advantaged families. In contrast to trends among the most affluent, we might 
expect Black parents to have an advantage here, in light of prior research showing that Black parents save more than White parents once background characteristics are controlled for (Steelman and Powell 1993). It may be that the Black advantage in parental college savings (net of controls) found in previous work is driven by relatively high savings in lower-income Black families. In this article, we further tease apart differences in parental college savings by considering how savings varies across the economic spectrum - thus showing how race and gender are associated with college savings for those with many and also few economic resources.

\section{Academic Factors and Parental College Savings}

Aside from economic factors as predictors of parental college savings, students' academic qualifications also play a key role. Here it is important to acknowledge that students' academic achievement is highly correlated with their family's economic circumstances, such that students from higher-SES families generally have much stronger academic credentials than their lower-SES peers (see e.g., Reardon 2011)_although the relationship between parental SES and student outcomes is stronger for Whites than for Blacks (Bumpus, Umeh, and Harris 2020). Notwithstanding these relationships, academic factors are fundamental to the study of parental college savings because parents use academic information to project their children's chances of college success - a process that generations of social scientists have considered (for a review, see Steelman and Powell 1991; Quadlin 2019). Scholars in the human capital tradition have long posited that high achievers receive more parental resources than low achievers because they are more likely to succeed in college and, eventually, the workforce (Becker 1964). In this theoretical perspective, parents may see high-achieving children as "safe bets" who are likely to yield a high return on investment. The status attainment model similarly predicts a positive relationship between children's academic performance and parental investment (Sewell, Haller, 
and Portes 1969). It follows, then, that parents may save additional resources for children with strong academic credentials, over and above what their economic resources would normally dictate.

In particular, recent research has highlighted the relationship between gender and academics. Throughout the K-12 years, girls and women generally have stronger academic performance than boys and men (Buchmann and DiPrete 2006). If parents are motivated to reinforce strong academic performance when setting aside resources for college, then it follows that girls should have more savings than boys on average. But at the same time, social and economic opportunity structures continue to advantage men in the U.S. (Ridgeway 2011). This dynamic could encourage parents to designate additional resources for boys, if parents are motivated to support children who will experience fewer obstacles in adulthood (Raley and Bianchi 2006).

We expect that the intersection of race and gender is particularly important in the case of academics. As noted above, research shows that gender gaps in college completion are outsized among Black students. Of the bachelor's degrees conferred to Black students in 2016-17, more than 64 percent were conferred to women (versus 57 percent among Whites; Snyder, de Brey, and Dillow 2019; also see DiPrete and Buchmann 2013; McDaniel et al. 2011). Therefore, despite having fewer economic resources on average than their White peers, Black women achieve relatively high rates of college completion, and thus they out-perform what would normally be projected for students with their economic profiles. This may put Black girls in a challenging situation, however, when it comes to parental college savings. Even if parents of Black girls are adjusting their college savings upward to be in line with their daughters' academic performance, as human capital theories would predict, these adjustments may 
eventually hit the ceiling of Black parents' economic circumstances. As a result, Black girlsand especially high-achieving Black girls — would disproportionately bear the brunt of any average racial differences in parental college savings. If this is the case, then Black girls may face acute economic challenges in funding higher education that can potentially have broader consequences, such as suppressing their college completion rate and deepening racial inequalities in debt and assets.

\section{The Current Study}

To reiterate, this article assesses race and gender differences in parental college savings. To account for the fact that students have different chances of attending college—and parents theoretically calibrate their savings to reflect those differential chances—our models incorporate students' chances of attending college as determined by both economic/family factors and academic factors. In addition to the main analyses that examine parental college savings in students' $11^{\text {th }}$ grade year, we also investigate the additional funding sources parents anticipate using to pay for their children's college. These analyses investigate race-gender differences in students' chances of using a range of financial instruments, including liquid earnings and savings; grants and scholarships; and government-backed and private loans (issued to either the student or the parent). We devote less space to these analyses in this literature review because we focus mostly on the issue of parental college savings. However, depending on whether these other funding sources must be repaid — not to mention who is responsible for repaying themthese anticipated funding sources can have lasting implications for economic well-being across race-gender groups. 


\section{DATA \& METHODS}

\section{Data}

We use data from the High School Longitudinal Study of 2009, the most recent nationally representative survey with information on parental college savings and pre-college social and academic experiences $(N=23,503)$. HSLS is a survey sponsored by the National Center for Education Statistics (NCES) that focuses on students' pathways through high school and post-secondary education. ${ }^{1}$ Respondents were first recruited in fall 2009, and follow-up interviews were conducted in 2012, 2013 (an abbreviated survey on students' college plans), and 2016. An additional follow-up is planned for 2025. Most of the variables we use come from the first student and parent follow-up surveys, conducted in 2012, when most students were juniors in high school. HSLS is unique among NCES surveys because of its focus on students' interest and experiences in STEM (i.e., science, technology, engineering, and mathematics). Although our primary interest is not STEM, the survey's focus on STEM has implications for some of the items we used (e.g., NCES conducted a math assessment but not other subjects that have historically been included in NCES surveys). The main limitation of the HSLS dataset for our purposes is that it does not contain information on parental wealth (aside from wealth that parents specifically report as college savings) —we discuss this limitation more throughout.

The sample is limited to students who identify as either White or Black, given that most research on race, debt, and assets addresses the Black-White divide, and we focus on squaring these findings with research on gender differences in college completion among Blacks and

\footnotetext{
${ }^{1}$ As a consequence of this survey design, the HSLS does not include data on nontraditional-aged students, who are becoming more common in higher education.
} 
Whites. ${ }^{2}$ The sample is smaller than that for other studies using HSLS data because the item about parental college savings was administered to a random sample $(n=7,426)$ of respondent parents. Once we account for this element of the survey design (and participation in a future round of the HSLS survey, as discussed below), item non-response in the HSLS is low, and we lose only 418 cases (less than 2 percent of the total) to missing data on the covariates. The final sample of 3,895 consists of students who are either White or Black, with complete data on all outcomes and covariates. Table 1 shows descriptive statistics for the variables, separated by our race-gender groups of interest.

\section{Parent-Reported College Savings}

The main dependent variable is parental college savings, which parents reported in the 2012 follow-up, when most students were in the spring of their $11^{\text {th }}$ grade year. This measure represents the financial resources explicitly reserved for college at a time when many students are starting to make concrete plans for their education beyond high school.

We use this variable in two forms: First, we examine whether any money is saved for the child's college education (yes/no). Second, we examine the amount of money saved among those who have saved for their child's college education, which removes the large number of respondents who reported zero savings. ${ }^{3}$ College savings is reported categorically in HSLS. We assigned each respondent the median value for their category, and top-coded this variable as 1.5 times the top category for those who reported savings in the highest range. Some parents may have made errors when reporting the amount they have saved, as is sometimes the case for

\footnotetext{
${ }^{2}$ Although some students identify as more than one race, the dataset does not indicate which races are included under the category of "multi-racial," so these students are excluded.

${ }^{3}$ Results are consistent when respondents who reported zero savings are included in these models.
} 
Table 1. Descriptive Statistics, High School Longitudinal Study of 2009 (HSLS:09), $N=3,895$

\begin{tabular}{|c|c|c|c|c|}
\hline & $\begin{array}{l}\text { White } \\
\text { Boys }\end{array}$ & $\begin{array}{l}\text { White } \\
\text { Girls }\end{array}$ & $\begin{array}{l}\text { Black } \\
\text { Boys }\end{array}$ & $\begin{array}{l}\text { Black } \\
\text { Girls }\end{array}$ \\
\hline \multicolumn{5}{|l|}{ Parental college savings } \\
\hline Saved anything? & .56 & .54 & $.34 *$ & $.38 *$ \\
\hline $\begin{array}{l}\text { Amount saved (among those who have saved, } \\
\text { in thousands) }{ }^{a}\end{array}$ & $\begin{array}{c}24.81 \\
(28.88)\end{array}$ & $\begin{array}{l}21.69 * \dagger \\
(26.59)\end{array}$ & $\begin{array}{c}11.56^{*} \\
(15.75)\end{array}$ & $\begin{array}{r}9.61^{*} \\
(14.01)\end{array}$ \\
\hline \multicolumn{5}{|l|}{ Economic/family factors } \\
\hline \multicolumn{5}{|l|}{ Family income } \\
\hline Bottom quintile & .06 & .06 & $.23 *$ & $.21 *$ \\
\hline Second quintile & .14 & .12 & $.34^{*}$ & $.22 * \dagger$ \\
\hline Third quintile & .27 & $.31 * \dagger$ & .31 & $.37 *$ \\
\hline Fourth quintile & .24 & .25 & $.07 *$ & $.14^{* \dagger}$ \\
\hline Top quintile & .30 & $.26 * \dagger$ & $.05^{*}$ & $.06^{*}$ \\
\hline \multicolumn{5}{|l|}{ Parent education } \\
\hline Less than high school & .02 & $.03 * \dagger$ & $.07 *$ & $.09 *$ \\
\hline High school diploma & .28 & .27 & .33 & $.36^{*}$ \\
\hline Occupational training & .05 & .05 & $.14^{*}$ & $.06 \dagger$ \\
\hline Associate's degree & .15 & .16 & .16 & $.21 *$ \\
\hline Bachelor's degree & .27 & .29 & $.18^{*}$ & $.16^{*}$ \\
\hline Master's degree & .16 & .15 & $.09^{*}$ & $.10^{*}$ \\
\hline $\mathrm{PhD}, \mathrm{MD}, \mathrm{JD}$, or other professional & .07 & $.05^{* \dagger}$ & $.02 *$ & $.02 *$ \\
\hline $\mathrm{R}$ parent is married or partnered & .76 & .77 & $.45^{*}$ & $.41 *$ \\
\hline \multirow[t]{2}{*}{ Number of siblings } & 2.03 & 2.10 & $3.13^{*}$ & $3.07 *$ \\
\hline & $(1.55)$ & $(1.52)$ & $(2.41)$ & $(2.24)$ \\
\hline High school is in urban area & .20 & .22 & $.39 *$ & $.43 *$ \\
\hline \multicolumn{5}{|l|}{ Academic factors } \\
\hline \multirow[t]{2}{*}{ Standardized math score } & 53.80 & 53.18 & $44.76^{*}$ & $47.22 * \dagger$ \\
\hline & $(10.39)$ & $(9.34)$ & $(8.48)$ & $(8.91)$ \\
\hline Took AP course & .38 & $.43 * \dagger$ & $.25 *$ & $.32 *$ \\
\hline All of student's friends plan to attend college & .15 & $20 *+$ & .19 & $.24 *$ \\
\hline \multicolumn{5}{|l|}{ Type of college parent anticipates } \\
\hline Haven't thought about it & .08 & $.05 * \dagger$ & $.14^{*}$ & .09 \\
\hline Occupational training & .10 & $.04 * \dagger$ & $.03^{*}$ & $.10 \dagger$ \\
\hline Two-year & .03 & .03 & .03 & $.07^{* \dagger}$ \\
\hline Four-year - Other details not specified & .12 & .11 & .14 & .13 \\
\hline Four-year - Public in state & .50 & $.55^{* \dagger}$ & .46 & $.43^{*}$ \\
\hline Four year - Public out of state & .06 & .06 & $.15^{*}$ & $.08 \dagger$ \\
\hline Four year - Private & .11 & $.16^{* \dagger}$ & $.06^{*}$ & $.11 \dagger$ \\
\hline \multicolumn{5}{|l|}{ Funding sources parents anticipate using } \\
\hline Parent's earnings/savings & .56 & .57 & $.41 *$ & $.38^{*}$ \\
\hline Student's earnings/savings & .39 & $.43^{*}+$ & .39 & $.32 *$ \\
\hline Scholarships or grants & .72 & $.79 * \dagger$ & $.79 *$ & $.83 *$ \\
\hline Federal or state loan & .61 & $.67 * \dagger$ & $.69 *$ & .66 \\
\hline Private loan in student's name & .24 & $.28 * \dagger$ & .27 & .27 \\
\hline Private loan in parent's name & .28 & .30 & $.37 *$ & $.38 *$ \\
\hline$n$ & 1,621 & 1,656 & 302 & 316 \\
\hline
\end{tabular}

Note: Descriptive statistics are weighted. Standard deviations for continuous variables in parentheses.

${ }^{a}$ Values are top-coded as 1.5 times the top category.

$* p<.05$ for comparison of race/gender group to white boys; $\uparrow p<.05$ for comparison between boys and girls within race groups. More detailed $p$-values are included in the main text where applicable. 
financial measures that are commonly included in surveys, such as household income. Assuming classical measurement error, the results we present below should be considered conservative estimates of differences between our groups of interest. Despite the possibility of measurement error here, the parent-reported data included in the HSLS are far preferable to student estimates of their parents' college savings, which are reported in some surveys.

\section{Funding Sources Parents Expect to Use for College}

We also examine whether parents expect to use each of six funding sources to pay for their children's college, as measured in the $11^{\text {th }}$ grade parent survey. These funding sources are listed in the bottom section of Table 1. Parents' or relatives' earnings/savings and student's earnings/savings reflect the economic resources available to parents and students. Scholarships or grants are typically either need-based or merit-based, and do not need to be repaid. Federal or state loans eventually do need to be repaid, but their interest rates and repayment plans are more forgiving than private loans in the parent's name or private loans in the student's name (Consumer Financial Protection Bureau 2012). Each of these funding sources was measured as a binary variable, where " 1 " indicates that the family plans to use the funding source, regardless of the amount they intend to use. Although we do not have information on how much the parents anticipate drawing from each of these sources, a parent's engagement with each of these funding sources is an indicator of their financial opportunities and constraints, as well as their broader approach toward parental investment. Importantly, these outcomes are not mutually exclusive, as families must often piece together multiple funding sources to pay for higher education.

\section{Independent Variables}

As discussed earlier, prior research has conceptualized parental college savings as a function of the child's chances of attending college. These chances are largely (although 
certainly not entirely) determined by the parents' ability to pay and the child's pre-college academic performance. To quantify these two dimensions, we adapt a method used by Brand and Xie (2010) to estimate each student's predicted probability of enrolling in college. Specifically, we take an outcome measured in a future round of the HSLS survey—whether the student was enrolled in college full-time in fall 2013 - and estimate each student's predicted probability of achieving that outcome. ${ }^{4}$ This method allows us to model the student's chances of attending college (which mirrors our theoretical argument about parents calculating their child's chances of college attendance), while also allowing us to combine multiple predictors into more succinct measures of economic and academic background.

We separate Brand and Xie's (2010) predictors into two models, representing the two separate dimensions we have theorized throughout. As listed in Table 1, Economic/family factors include: family income; the highest level of education completed by either parent; whether the respondent parent is married or partnered; number of siblings; and whether the student's high school is located in an urban area. Academic factors include: the student's score on an NCESadministered math test; whether the student took at least one AP course; and whether the student believes "all" their friends plan to attend a four-year college. We use these two sets of variables as predictors, with future college enrollment as the outcome, to generate two separate measures: students' predicted probability of attending college as determined by (1) economic/family factors and (2) academic factors, which we use separately in the analyses. Most of our predictors are the same as those used in Brand and Xie (2010), but there are some differences and omissions

\footnotetext{
${ }^{4}$ Brand and Xie (2010) use this method to assess students' chances of completing college, so their outcome is college completion. The HSLS survey is too new to have captured college completion, so we use full-time college enrollment in the fall after high school graduation. Ontime college enrollment has been shown to predict college completion (Carbonaro, Ellison, and Covay 2011), so our measure can be viewed as a rough precursor to college completion.
} 
because we rely on different datasets - we compare our variables with Brand and Xie's (2010) in Appendix A in the online supplement. Of course, economic/family and academic factors are highly interrelated, and we recognize that it is not possible to isolate the effects of one of these sets of factors without also introducing aspects of the other. Yet, we use these factors separately in models to understand to what extent they are related to parental college savings independently.

Figure 1 shows the distributions of each of these predicted probabilities for our four racegender groups of interest: White boys, White girls, Black boys, and Black girls. Predicted probabilities of attending college based on economic/family factors are shown in the left column, and predicted probabilities based on academic factors are shown in the right column. These distributions show a clear divide between White and Black students. White boys and girls generally have higher predicted probabilities of attending college than their Black peers. Black boys' probabilities are perhaps the closest to normally distributed, with many students having moderate predicted probabilities of attending college. Black girls' probabilities, in the bottom row, tend to be normally distributed when we consider economic/family factors, reflecting their moderate economic circumstances. At the same time, Black girls' probabilities are more negatively skewed when we consider academic factors, reflecting their strong academic qualifications. This apparent contradiction between the economic and academic circumstances of Black girls is an important dynamic that we will consider further throughout the analyses.

In addition to the predictors described above, the models account for the type of college the parent expects the student to attend in the fall after high school graduation, if any (see Table 1). We control for this measure because different types of colleges are generally linked to different costs of attendance, and parental savings could be dialed either up or down depending on what parents expect to pay (although high sticker prices do not necessarily translate to high 
Figure 1. Distributions of Predicted Probabilities of Enrolling in College, Based on Economic/Family Factors (Left Column) and Academic Factors (Right Column)

Economic/Family Factors

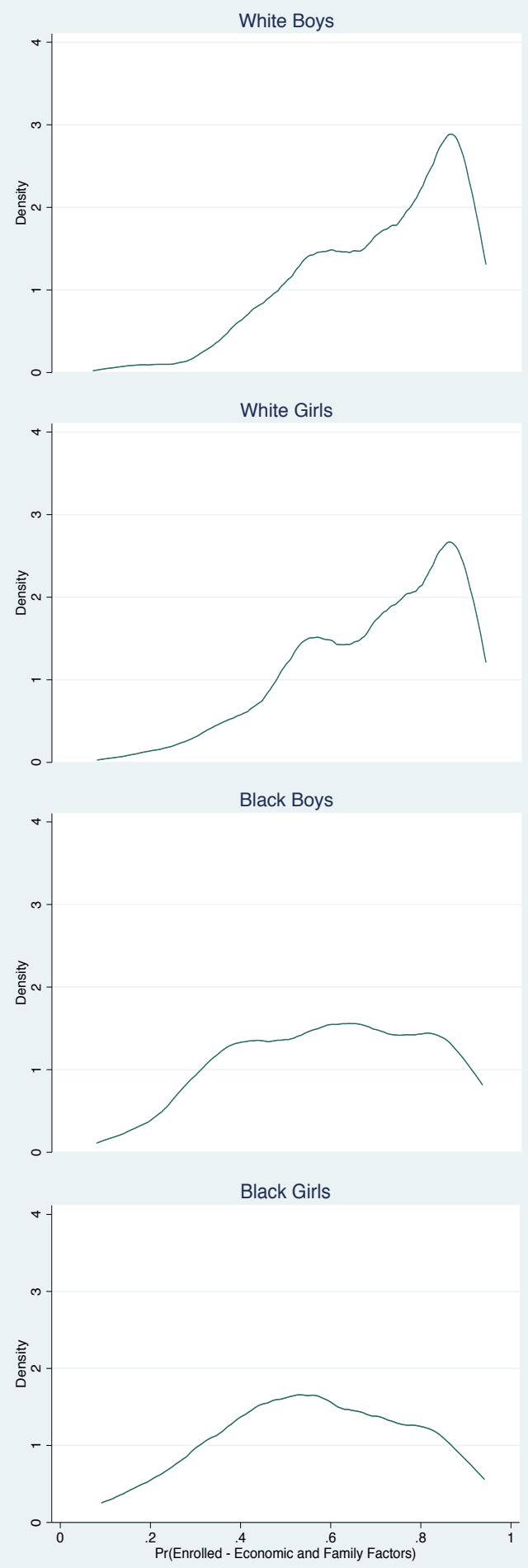

Academic Factors

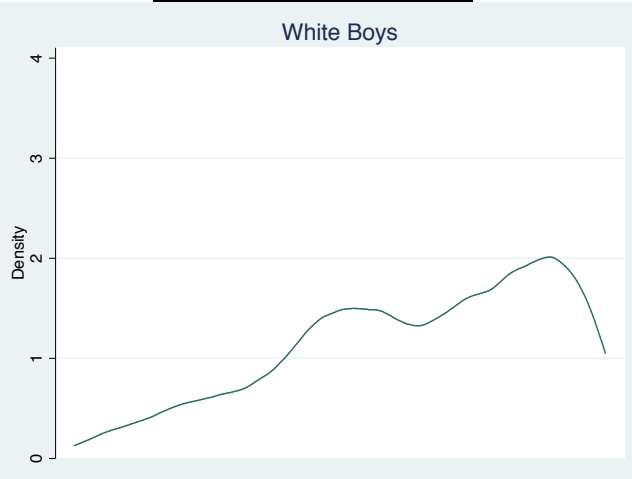

White Girls

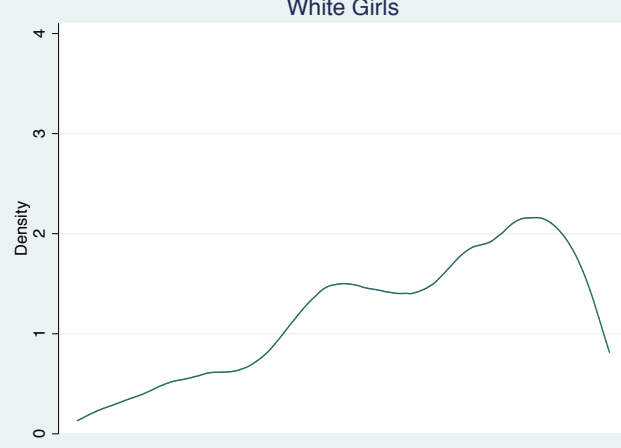

Black Boys

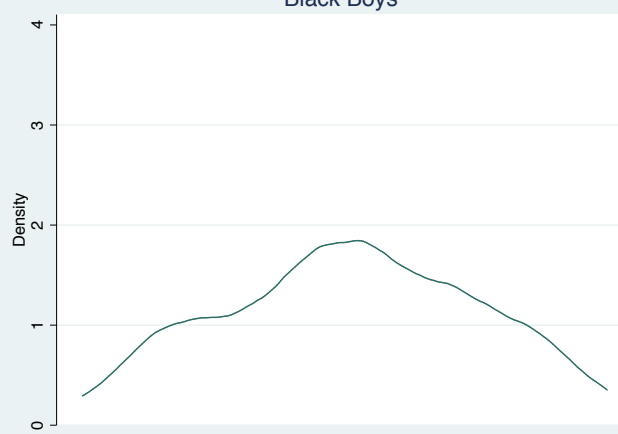

Black Girls

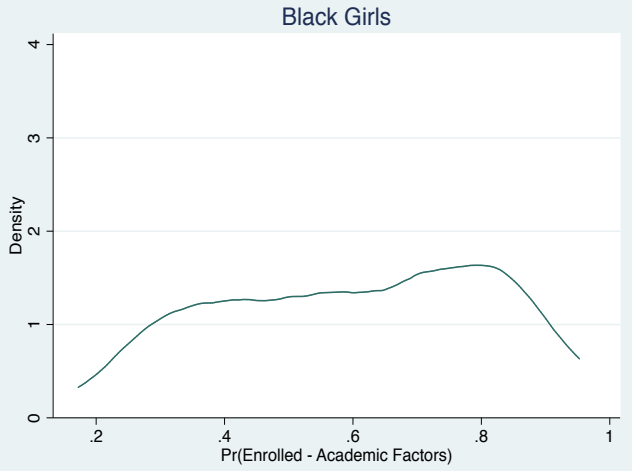

Source: High School Longitudinal Study of 2009. 
out-of-pocket costs, especially for low-income students - which we discuss throughout the results and conclusion).

\section{Analytic Strategy}

We begin by assessing basic differences in parental college savings. Here we consider how race, gender, and their intersections, along with the other predictor variables of interest, are associated with parental college savings. Then we incorporate our predicted probability measures to determine how students' chances of attending college, as dictated by economic/family and academic factors, are related to college savings. As a final component, we examine how students' predicted probabilities of enrolling in college are associated with the funding sources parents expect to use to pay for college. We assess how these anticipated funding sources differ at various probabilities of college enrollment (again separately for economic/family and academic predictors), and across race-gender groups.

\section{RESULTS}

\section{Race, Gender, and Patterns of College Savings}

We begin by assessing mean differences in parental college savings for White boys, White girls, Black boys, and Black girls. Before turning to the multivariable models that account for sociodemographic controls, the descriptive statistics in Table 1 show average parental college savings across race-gender groups. As indicated in Table 1, saving for college is by no means universal among parents. Fifty-six percent of parents of White boys have saved anything by their child's $11^{\text {th }}$ grade year, versus 54 percent of parents of White girls. This figure drops to 34 
percent and 38 percent for parents of Black boys and Black girls, respectively (both $p<.001$ compared to White boys). ${ }^{5}$

Table 1 also reveals significant race-gender differences in the amount parents have saved for college, conditional on having saved. Parents of White boys report saving an average of $\$ 24,810$, compared to $\$ 21,693$ for White girls $(p<.05)$. Parents of Black boys $(\$ 11,559)$ and Black girls $(\$ 9,611)$ report saving substantially less than parents of White boys (both $p<.001$ ).

The multivariable models in Table 2 assess the extent to which these significant mean differences diminish once other control variables are accounted for. Model 1 examines whether parents have saved anything for college, using logistic regression. Here we see that the significant race-gender gaps dissipate once other control variables are included in the modelparticularly economic and family factors such as family income and the child's number of siblings. Model 2 is a linear regression that gauges parents' amount saved, conditional on having saved. The difference between White boys and girls again dissipates, but here we observe a gap between White boys and Black boys and girls. When we include controls-including a control for Black students' substantial family income disadvantage relative to White boys—Black students continue to face a savings disadvantage, equal to approximately $\$ 5,000$ for both Black boys $(p<.05)$ and Black girls $(p<.01)$. To summarize, then, after accounting for a comprehensive set of economic, family, and academic factors, parents of students in all four race-gender groups are equally likely to have put away at least some money for college— but even these extensive controls do not account for the disparities in the amount saved between race-gender groups, with race emerging as the main stratifying factor.

\footnotetext{
${ }^{5}$ Throughout this article, in tables with separate columns for race-gender groups, we use a single asterisk $(*)$ to denote $p<.05$ due to space constraints in the tables, but we use more detailed $p$ values when referring to comparisons in the main text.
} 
Table 2. Effects of Race, Gender, Economic/Family Factors, and Academic Factors on Parental College Savings

\begin{tabular}{|c|c|c|}
\hline & $\begin{array}{c}\begin{array}{c}\text { Saved } \\
\text { anything? }\end{array} \\
\text { (1) } \\
\end{array}$ & $\begin{array}{c}\text { Amount saved } \\
\text { (among those who } \\
\text { have saved), in } \\
\text { thousands of dollars } \\
\text { (2) }\end{array}$ \\
\hline White girls & $\begin{array}{l}-0.08 \\
(0.10)\end{array}$ & $\begin{array}{l}-2.50 \\
(1.37)\end{array}$ \\
\hline Black boys & $\begin{array}{l}-0.28 \\
(0.21)\end{array}$ & $\begin{array}{l}-5.15^{*} \\
(2.25)\end{array}$ \\
\hline Black girls & $\begin{array}{l}-0.23 \\
(0.21)\end{array}$ & $\begin{array}{l}-4.96^{* *} \\
(1.76)\end{array}$ \\
\hline Family income & & \\
\hline Second quintile & $\begin{array}{c}0.41 \\
(0.23)\end{array}$ & $\begin{array}{l}-2.65 \\
(3.71)\end{array}$ \\
\hline Third quintile & $\begin{array}{l}0.69^{* *} \\
(0.22)\end{array}$ & $\begin{array}{l}-1.18 \\
(3.56)\end{array}$ \\
\hline Fourth quintile & $\begin{array}{l}1.02^{* * * *} \\
(0.23)\end{array}$ & $\begin{array}{c}0.27 \\
(3.73)\end{array}$ \\
\hline Fifth quintile & $\begin{array}{l}1.78^{* * *} \\
(0.24)\end{array}$ & $\begin{array}{l}17.09^{* * *} \\
(3.87)\end{array}$ \\
\hline Parent education & & \\
\hline High school diploma & $\begin{array}{c}0.05 \\
(0.35)\end{array}$ & $\begin{array}{c}3.59 \\
(2.91)\end{array}$ \\
\hline Occupational training & $\begin{array}{c}0.47 \\
(0.40)\end{array}$ & $\begin{array}{c}3.22 \\
(3.12)\end{array}$ \\
\hline Associate's degree & $\begin{array}{c}0.49 \\
(0.37)\end{array}$ & $\begin{array}{c}4.93 \\
(2.85)\end{array}$ \\
\hline Bachelor's degree & $\begin{array}{c}0.69 \\
(0.36)\end{array}$ & $\begin{array}{l}8.72^{* *} \\
(3.00)\end{array}$ \\
\hline Master's degree & $\begin{array}{c}0.58 \\
(0.38)\end{array}$ & $\begin{array}{l}9.17^{* *} \\
(3.22)\end{array}$ \\
\hline $\mathrm{PhD}, \mathrm{MD}$, JD, or other professional & $\begin{array}{c}0.75 \\
(0.42)\end{array}$ & $\begin{array}{l}21.24 * * * \\
(4.23)\end{array}$ \\
\hline Parent married & $\begin{array}{l}-0.25^{*} \\
(0.12)\end{array}$ & $\begin{array}{l}-4.11 * * \\
(1.55)\end{array}$ \\
\hline Number of siblings & $\begin{array}{l}-0.15^{* * *} \\
(0.03)\end{array}$ & $\begin{array}{l}-1.87^{* * *} \\
(0.34)\end{array}$ \\
\hline Urban high school & $\begin{array}{c}0.13 \\
(0.11)\end{array}$ & $\begin{array}{c}2.51 \\
(1.46)\end{array}$ \\
\hline Math score & $\begin{array}{c}0.01 \\
(0.01)\end{array}$ & $\begin{array}{c}0.14 \\
(0.08)\end{array}$ \\
\hline Took AP & $\begin{array}{c}0.19 \\
(0.11)\end{array}$ & $\begin{array}{c}0.46 \\
(1.37)\end{array}$ \\
\hline
\end{tabular}




\begin{tabular}{|c|c|c|}
\hline Friends all enrolling & $\begin{array}{c}0.09 \\
(0.13)\end{array}$ & $\begin{array}{c}4.26^{*} \\
(1.66)\end{array}$ \\
\hline \multicolumn{3}{|c|}{ Parents anticipate student will attend } \\
\hline Occupational training & $\begin{array}{c}0.64 * \\
(0.27)\end{array}$ & $\begin{array}{l}-1.10 \\
(3.17)\end{array}$ \\
\hline Two-year & $\begin{array}{c}0.52 \\
(0.33)\end{array}$ & $\begin{array}{c}1.96 \\
(5.83)\end{array}$ \\
\hline Four-year unspecified & $\begin{array}{l}0.91^{* * *} \\
(0.23)\end{array}$ & $\begin{array}{c}2.38 \\
(2.94)\end{array}$ \\
\hline Public in-state & $\begin{array}{l}0.89^{* * *} \\
(0.20)\end{array}$ & $\begin{array}{l}-1.97 \\
(2.44)\end{array}$ \\
\hline Public out-of-state & $\begin{array}{l}1.15^{* * *} \\
(0.26)\end{array}$ & $\begin{array}{c}0.70 \\
(3.17)\end{array}$ \\
\hline Private & $\begin{array}{l}0.93^{* * *} \\
(0.24)\end{array}$ & $\begin{array}{l}8.37^{* *} \\
(3.02)\end{array}$ \\
\hline Constant & $\begin{array}{l}-1.94^{* * * *} \\
(0.47)\end{array}$ & $\begin{array}{c}6.70 \\
(4.92)\end{array}$ \\
\hline$N / n$ & 3,895 & 2,129 \\
\hline
\end{tabular}

Source: High School Longitudinal Study of 2009.

Note: Robust standard errors in parentheses. Analyses are weighted. Omitted categories are white boys, bottom income quintile, parent education is less than high school, R parent not married or partnered, suburban or rural high school, did not take AP course, not all friends enrolling, parents haven't thought about type of college child will attend.

$* p<.05, * * p<.01, * * * p<.001$ (two-tailed tests)

\section{Accounting for Predicted Probability of Enrollment}

These initial models are important for understanding how parental college savings is associated with race, gender, and other factors on average. But how are these processes further complicated by students' chances of attending college? Prior research has posited that parents save for college in accordance with their child's realistic chances of actually attending college, as determined by their ability to pay and the child's academic performance. Accordingly, we assess parental college savings for White boys, White girls, Black boys, and Black girls along those two dimensions. 
Figure 2 shows parents' chances of having saved anything for college, over the range of students' predicted probabilities of enrollment. ${ }^{6}$ The top panels illustrate how students' predicted probability of enrolling in college, as determined by economic/family factors, is related to their parents' chances of having saved. The trendlines for White boys and girls show a clear positive relationship between chances of enrollment, based on family circumstances, and savings. As students' economic and family circumstances are more favorable, and their chances of enrollment increase in turn, their parents' chances of having saved also increase substantially. This is also the case for Black boys, although their positive slope is muted by comparison. Black girls have the flattest trend line: we observe no difference in the probability of having saved between Black girls with highest chances of college enrollment, versus those with the lowest chances of enrollment ( $p=.09$, not shown). This pattern suggests that Black girls experience null returns to their economic and family circumstances when it comes to having a college savings account, which is not the case for any of the other three race-gender groups. As a result, we observe clear differences in parents' chances of saving between Black girls and students in other race-gender groups who have equal economic probabilities of attending college. To give just one example, among those whose economic circumstances make them almost certain to attend college (i.e., economic probability= 90 ), Black girls have just over a .50 probability of having any money saved, compared to nearly .75 for White girls.

We also observe racial differences among girls at both the top and bottom of the distribution. At the top of the distribution (at about the .80 probability level and above), parents of White girls are more likely to have saved. But at the bottom of the distribution, parents of

\footnotetext{
${ }^{6}$ The underlying regressions for Figures 2 and 3 are shown in Appendix B in the online supplement.
} 
Figure 2. Predicted Probability of Parents Having Saved for Child's College Education, $N=3,895$

(A)- Student's Probability of Enrollment Estimated with Economic/Family Factors

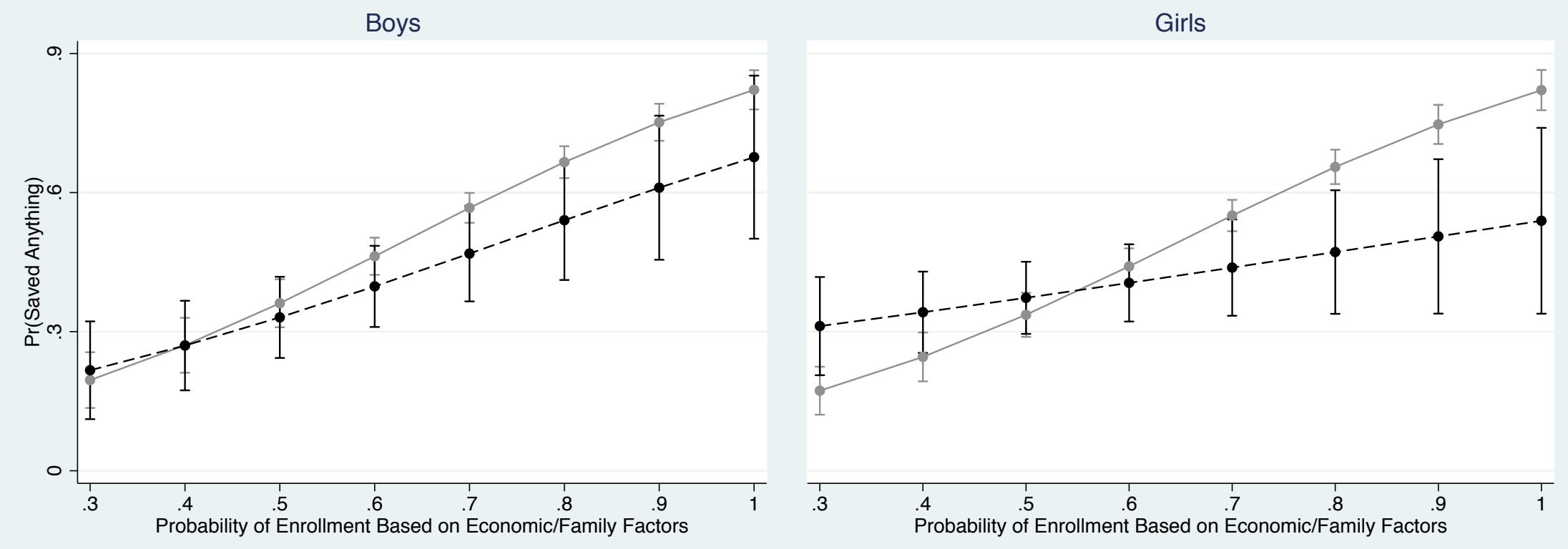

(B) - Student's Probability of Enrollment Estimated with Academic Factors

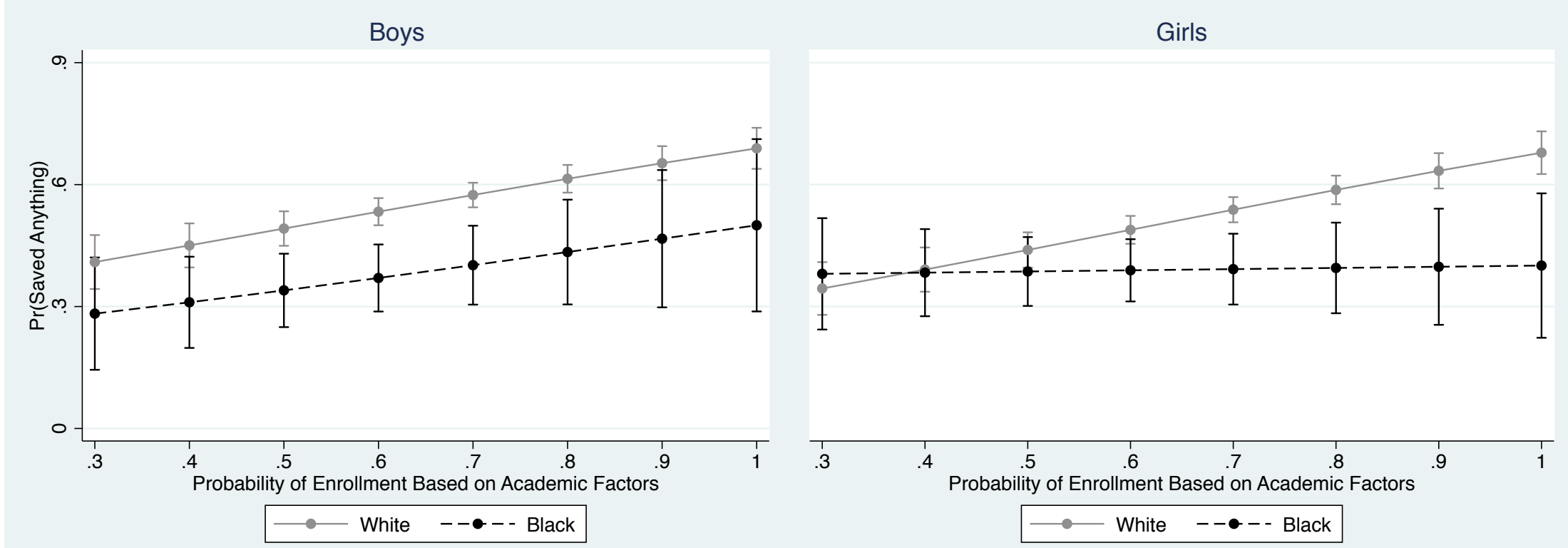

Source: High School Longitudinal Study of 2009. Note: Models include control for type of college the respondent parent anticipates the child will attend in the fall (if any). 
Black girls are more likely to have saved. Thus, Black girls do not experience clear returns to economic and family circumstances - but when their chances of college enrollment are relatively low as dictated by these circumstances, Black girls are more likely than their White counterparts to receive at least some amount of parental investment.

The bottom panels of Figure 2 show the relationship between students' probability of enrolling in college, as predicted by academic factors, and their parents' chances of having saved. Again we see a distinct positive relationship for White boys and girls. But from the perspective of disparities in savings, the more consequential pattern here relates to the trendlines for Black boys and, especially, Black girls. For Black students, academic advantages do not translate to savings advantages in the same way they do for Whites. Among both Black boys and Black girls, we observe a null relationship between probability of enrollment based on academic factors and parents' chances of saving for college. In other words, parents of the most academically successful Black boys and girls are no more likely to have saved than parents of the least academically successful. The trendline for Black girls, in particular, is virtually flat. To continue with the example given earlier, a Black girl whose academic credentials make her virtually guaranteed to attend college (i.e., academic probability=.90) is nearly equally likely to have college savings as a Black girl with a .30 academic probability of attending college. This translates to increasingly large gaps in savings between Black and White girls who are academically equivalent.

Figure 3 builds on these patterns by examining the amount saved (conditional on having saved), over the range of students' predicted probabilities of enrollment. The top panels show estimates over the range of students' probability of enrollment, as predicted by economic/family factors. For all race-gender groups, there is a clear positive relationship between economic and 
Figure 3. Amount Parents Have Saved for Child's College Education, $n=2,129$

(A) - Student's Probability of Enrollment Estimated with Economic/Family Factors
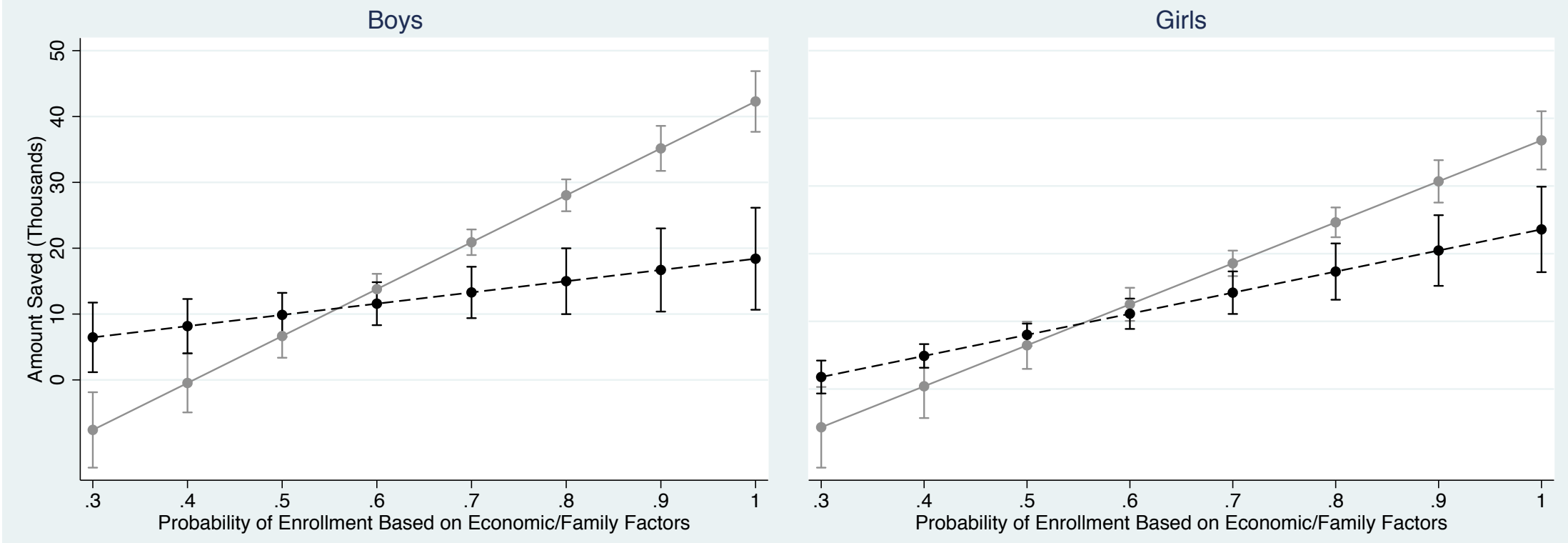

(B) - Student's Probability of Enrollment Estimated with Academic Factors

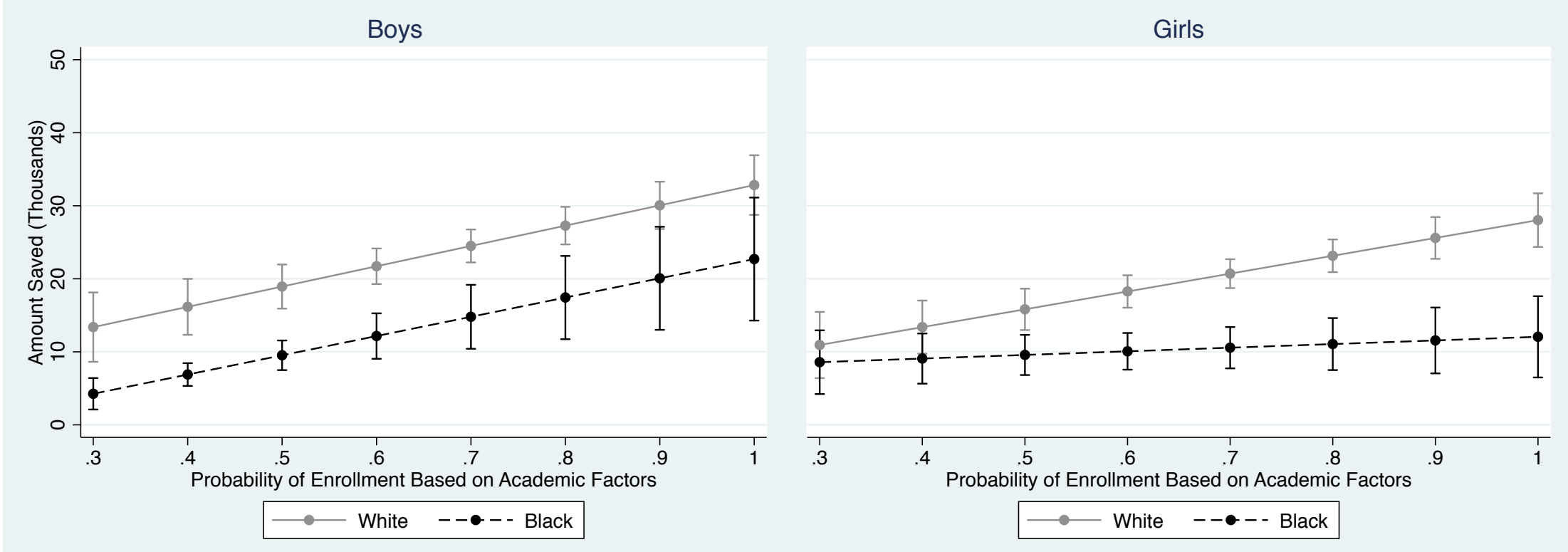

Source: High School Longitudinal Study of 2009. Note: Models include control for type of college the respondent parent anticipates the child will attend in the fall (if any). 
family circumstances and college savings. Students with more favorable economic and family circumstances generally have higher balances in their college savings accounts, conditional on having savings. Yet, the amount saved differs substantially by race. Toward the top of the distribution, parents of White boys and girls have saved substantially more than their Black counterparts, with an especially large gap of about $\$ 24,000$ between White boys and Black boys. At the bottom of the distribution, Black boys and girls both experience a savings advantage. Thus, among those with few economic resources, Black parents tend to make greater investments in their children's college education than White parents.

The bottom panels show estimates over the range of students' probability of enrollment, as predicted by academic factors. As White boys and Black boys have stronger academic records, and their chances of college enrollment increase in turn, their parents tend to save more for college (conditional on having saved). At the same time, parents of White boys save significantly more than parents of Black boys. This pattern also generally holds for White girls in the right panel. Yet, this is clearly not the case for Black girls. In terms of the amount of parental college savings, the most academically successful Black girls are virtually no different than the least academically successful Black girls. As a result, White girls at the top of the distribution have more than double the college savings of equally qualified Black girls (about $\$ 28,000$ versus about $\$ 12,000)^{7}$

Why is it that Black students' chances of enrolling in college often have a null relationship with their parents' chances of saving or the amount saved? One possible explanation is that Black students with a high academic probability of college enrollment have relatively low

\footnotetext{
${ }^{7}$ Supplementary analyses show that results are consistent when we use the natural log of income as the outcome; see Appendix $\mathrm{C}$ in the online supplement.
} 
college savings because they are disadvantaged in terms of economic and family factors. To investigate this dynamic, we compared the economic and family circumstances of students in different race-gender groups at various levels of predicted college enrollment. Results from this supplemental analysis are shown in Table 3. Cell sizes would normally be too small to produce reliable descriptive statistics for each race-gender group, and especially to conduct significance tests across groups. To navigate this issue, we used regressions to estimate predicted values for each of our economic/family predictors for students at different academic probabilities of attending college-i.e., academic probabilities of $.30, .70$, and $.95 .{ }^{8}$ These regressions use the full sample of respondents to make estimates at the academic percentiles of interest, essentially producing estimates that are more stable than if we were to use data from only those students in a given probability band. ${ }^{9}$

The results in Table 3 help explain why Black boys, and especially Black girls, tend to receive less college savings than White boys and girls with similar academic qualifications. In each of these panels, Black students experience more economic and family constraints than their White peers. Specifically, in each probability band, Black girls (in terms of sheer point estimates and compared to those in other race-gender groups): are the most likely to be in the bottom quintile, and least likely to be in the top quintile of parental income; are the most likely to have parents with only a high school diploma, and least likely to have parents with advanced degrees;

\footnotetext{
${ }^{8}$ These probabilities correspond to about the $5^{\text {th }}$ percentile, the $50^{\text {th }}$ percentile, and the $95^{\text {th }}$ percentile, but our conclusions were consistent regardless of the exact probabilities we used. ${ }^{9}$ Specifically, we used each of the economic/family variables as the outcome and used (1) the race-gender groups and (2) an interaction between the race-gender groups and students' academic probability of enrolling in college as predictors. Estimates for the economic/family variables are generated by holding the academic probability at specified values (i.e., $.30, .70$, and .95). For a discussion of similar methods, see Bassok and colleagues (2016) and Reardon (2011).
} 
Table 3. Descriptive Statistics, by Academic Predicted Probability of Enrolling in College

\begin{tabular}{|c|c|c|c|c|}
\hline & $\begin{array}{l}\text { White } \\
\text { Boys }\end{array}$ & $\begin{array}{l}\text { White } \\
\text { Girls }\end{array}$ & $\begin{array}{c}\text { Black } \\
\text { Boys }\end{array}$ & $\begin{array}{c}\text { Black } \\
\text { Girls }\end{array}$ \\
\hline \multicolumn{5}{|l|}{.30 Academic Probability of Enrollment } \\
\hline \multicolumn{5}{|l|}{ Family income } \\
\hline Bottom quintile & .11 & .17 & $.31 *$ & $.34 *$ \\
\hline Second quintile & .27 & .30 & .29 & .25 \\
\hline Third quintile & .43 & .41 & .37 & .34 \\
\hline Fourth quintile & .17 & .16 & $.06^{*}$ & $.08 *$ \\
\hline Top quintile & .09 & .07 & $.04 *$ & $.03 *$ \\
\hline \multicolumn{5}{|l|}{ Parent education } \\
\hline Less than high school & .03 & $.09 * \dagger$ & .04 & $.12 *$ \\
\hline High school diploma & .53 & .50 & $.41 *$ & .49 \\
\hline Occupational training & .11 & .16 & .15 & .09 \\
\hline Associate's degree & .24 & .24 & $.15^{*}$ & .23 \\
\hline Bachelor's degree & .16 & .12 & .22 & $.08 * \dagger$ \\
\hline Master's degree & .05 & .05 & .06 & .05 \\
\hline $\mathrm{PhD}, \mathrm{MD}, \mathrm{JD}$, or other professional & .01 & .01 & .01 & .00 \\
\hline $\mathrm{R}$ parent is married (yes/no) & .65 & .62 & $.46^{*}$ & $.33 *$ \\
\hline Number of siblings & 2.24 & $2.52 * \dagger$ & $3.42 *$ & $3.61 *$ \\
\hline Urban h.s. (yes/no) & .15 & .18 & .22 & $.31 *$ \\
\hline \multicolumn{5}{|l|}{.70 Academic Probability of Enrollment } \\
\hline \multicolumn{5}{|l|}{ Family income } \\
\hline Bottom quintile & .05 & .04 & $.09 *$ & $.10^{*}$ \\
\hline Second quintile & .10 & .11 & $.18^{*}$ & $.20^{*}$ \\
\hline Third quintile & .27 & .30 & $.34 *$ & $.35^{*}$ \\
\hline Fourth quintile & .24 & .24 & $.16^{*}$ & $.18^{*}$ \\
\hline Top quintile & .29 & $.25 * \dagger$ & $.19^{*}$ & $.13^{*}$ \\
\hline \multicolumn{5}{|l|}{ Parent education } \\
\hline Less than high school & .01 & .01 & .02 & $.04 *$ \\
\hline High school diploma & .24 & .25 & .19 & $.28 \dagger$ \\
\hline Occupational training & .04 & .04 & .07 & .06 \\
\hline Associate's degree & .14 & .15 & $.20 *$ & .16 \\
\hline Bachelor's degree & .29 & .27 & $.21 *$ & .23 \\
\hline Master's degree & .15 & .14 & .20 & .13 \\
\hline $\mathrm{PhD}, \mathrm{MD}, \mathrm{JD}$, or other professional & .05 & .05 & .07 & .03 \\
\hline $\mathrm{R}$ parent is married (yes/no) & .79 & .78 & $.59 *$ & $.52 *$ \\
\hline Number of siblings & 2.04 & 2.07 & $2.72 *$ & $2.83^{*}$ \\
\hline Urban h.s. (yes/no) & .27 & .28 & .27 & $.33^{*}$ \\
\hline \multicolumn{5}{|l|}{.95 Academic Probability of Enrollment } \\
\hline \multicolumn{5}{|l|}{ Family income } \\
\hline Bottom quintile & .03 & .02 & .04 & .04 \\
\hline Second quintile & .05 & .05 & $.13^{*}$ & $.17 *$ \\
\hline Third quintile & .19 & $.24 * \dagger$ & $.32 *$ & $.36^{*}$ \\
\hline Fourth quintile & .29 & .30 & .29 & .29 \\
\hline Top quintile & .50 & .47 & .40 & $.27 *$ \\
\hline \multicolumn{5}{|l|}{ Parent education } \\
\hline Less than high school & .00 & .00 & .02 & .02 \\
\hline High school diploma & .13 & .15 & .11 & .18 \\
\hline Occupational training & .02 & .02 & .04 & .05 \\
\hline Associate's degree & .10 & .11 & $.24 *$ & .13 \\
\hline Bachelor's degree & .39 & .42 & $.21 *$ & $.39 \dagger$ \\
\hline Master's degree & .27 & .27 & .35 & .24 \\
\hline $\mathrm{PhD}, \mathrm{MD}, \mathrm{JD}$, or other professional & .19 & .16 & .18 & .15 \\
\hline $\mathrm{R}$ parent is married (yes/no) & .85 & .86 & $.67 *$ & $.63^{*}$ \\
\hline Number of siblings & 1.91 & 1.79 & 2.29 & $2.34^{*}$ \\
\hline Urban h.s. (yes/no) & .36 & .36 & .31 & .35 \\
\hline
\end{tabular}

Source: High School Longitudinal Study of 2009.

$* p<.05$ for comparison of race/gender group to white boys; $\uparrow p<.05$ for comparison between boys and girls within race groups. More detailed $p$-values are included in the main text where applicable. 
are the least likely to have married parents; and are raised in households with the largest number of siblings.

These constraints are perhaps most pronounced in the bottom panel, which shows estimates for students with a .95 academic probability of attending college. Substantively, one can think of these students as some of the most academically qualified $11^{\text {th }}$ graders in this nationally representative sample. Here we see that the most academically qualified Black students come from families that are much less well-off than comparable White students, and Black girls are again particularly disadvantaged —including relative to equally high-achieving Black boys. The modal White boy, White girl, and Black boy in this probability band comes from a family in the top income quintile. Meanwhile, the modal Black girl comes from a family in the third income quintile, which clearly demonstrates the exceptionality of high-achieving Black girls compared to their peers in other race-gender groups.

Taken together, for Black students, academic credentials may only take them so far when it comes to their college savings accounts. Even when they are among the most highly qualified from an academic standpoint, Black students — and particularly Black girls — may have relatively little college savings because they have far fewer economic advantages, and face far more family constraints, than their White peers.

\section{How do Parents Anticipate Paying for College?}

As a final component of the analysis, we assessed how race, gender, and students' chances of attending college are associated with the funding sources parents plan to use to cover their children's college costs. As discussed earlier, we use data on six funding sources: parents' earnings/savings; student's earnings/savings; scholarships or grants; federal or state loans; private loans in the student's name; and private loans in the parents' names. These anticipated 
funding sources reflect financial opportunities and constraints across race-gender groups, as well as parents' broader approaches toward parental investment.

Table 4 shows parents' anticipated funding sources stratified by students' economic/family probability of enrollment—in other words, how parents plan to pay for their children's college costs at three levels of economic advantage and constraint. ${ }^{10}$ The top section shows predictions for parents who face considerable economic constraints. In general, these parents have similar plans for paying for higher education across race-gender groups. In one notable exception, parents of Black boys $(p<.05)$ and Blacks girls $(p<.001)$ are more likely than parents of White boys to anticipate using a parent's earnings or savings. This finding is consistent with our earlier observation that the most financially disadvantaged Black students tend to receive more college savings than their White counterparts.

The bottom section of Table 4 shows parents' anticipated funding sources among the most economically advantaged families. Although these families are virtually guaranteed to send their children to college as dictated by their economic and family circumstances, we see distinct differences in funding sources across race-gender groups. Most notably, nearly all parents of White students expect to pay for at least part of college with their own earnings or savings - but this is not the case for parents of Black students (both $p<.01$ ). This pattern is consistent with our earlier results regarding lack of college savings among affluent Black parents. Notably, parents of Black students are more likely than parents of White boys to expect scholarships or grants (both $p<.01$ ). This pattern is suggestive of two potential causal mechanisms - either Black parents are hopeful that their children will receive scholarships to make up for their lack of

${ }^{10}$ The underlying regressions for Table 4 are shown in Appendix D in the online supplement. 
Table 4. Parents' Anticipated Funding Sources - by Economic/Family Probability of Enrolling in College

\begin{tabular}{lllll}
\hline & $\begin{array}{c}\text { White } \\
\text { Boys }\end{array}$ & $\begin{array}{c}\text { White } \\
\text { Girls }\end{array}$ & $\begin{array}{c}\text { Black } \\
\text { Boys }\end{array}$ & $\begin{array}{c}\text { Black } \\
\text { Girls }\end{array}$ \\
\hline 30 Economic/Family Probability of Enrollment & & & \\
\hline Parent's earnings/savings & .12 & .17 & $.23^{*}$ & $.27^{*}$ \\
Student's earnings/savings & .40 & .43 & .37 & .33 \\
Scholarships/grants & .79 & .84 & .78 & .84 \\
Federal or state loans & .73 & .71 & .66 & .70 \\
Private loan in student's name & .23 & .23 & .24 & .30 \\
Private loan in parent's name & .23 & .22 & .24 & .29 \\
\hline 70 Economic/Family Probability of Enrollment & & & \\
\hline Parent's earnings/savings & .57 & .57 & .50 & .51 \\
Student's earnings/savings & .39 & .40 & $.29^{*}$ & $.31^{*}$ \\
Scholarships/grants & .75 & $.79^{* \dagger}$ & $.84^{*}$ & $.85^{*}$ \\
Federal or state loans & .61 & .64 & $.69^{*}$ & $.68^{*}$ \\
Private loan in student's name & .25 & .25 & .27 & .26 \\
Private loan in parent's name & .28 & .29 & .35 & $.37^{*}$ \\
\hline 95 Economic/Family Probability of Enrollment & & & \\
\hline Parent's earnings/savings & .84 & .81 & $.68^{*}$ & $.66^{*}$ \\
Student's earnings/savings & .38 & .38 & $.25^{*}$ & .30 \\
Scholarships/grants & .72 & .75 & $.87^{*}$ & $.85^{*}$ \\
Federal or state loans & .53 & $.60^{*} \dagger$ & $.69^{*}$ & $.67^{*}$ \\
Private loan in student's name & .26 & .27 & .29 & .24 \\
Private loan in parent's name & .32 & .35 & .42 & .43 \\
\hline
\end{tabular}

Source: High School Longitudinal Study of 2009.

Note: Logistic regressions; predicted probabilities reported. Models include control for type of college the respondent parent anticipates the child will attend in the fall (if any). Sample sizes are: 3,833 (parent's earnings/savings); 3,836 (student's earnings/savings); 3,833

(scholarships/grants); 3,834 (federal or state loans); 3,831 (private loan in student's name); 3,837 (private loan in parent's name).

$* p<.05$ for comparison of race/gender group to white boys; $\dagger p<.05$ for comparison between boys and girls within race groups. More detailed $p$-values are included in the main text where applicable.

savings; or Black parents have been less intentional about saving because they are enthusiastic about their children's academic performance and are optimistic they will receive scholarships.

In addition, parents of Black boys are less likely than parents of White boys to expect students to contribute their own earnings or savings $(p<.01)$. Perhaps Black boys have few personal resources to draw on at the time of college enrollment, or their parents would prefer to pay for college through other sources that impose less of a personal burden. Finally, we find that 
compared to parents of White boys, parents of White girls $(p<.05)$, Black boys $(p<.01)$, and Black girls $(p<.05)$ are more likely to anticipate use of government loans. Thus, among students from relatively affluent families, White boys may be least often affected by the burdens of educational debt.

Table 5 shows parents' anticipated funding sources, this time stratified by the student's academic probability of enrollment. ${ }^{11}$ The top section of the table shows anticipated funding sources for students with among the weakest academic credentials. Among parents of these less qualified students, most anticipated funding sources are comparable across race-gender groups, with the exception of scholarships. Compared to parents of White boys, parents of White girls, Black boys, and Black girls (all $p<.05$ ) are more likely to indicate they will pay for at least part of college with a scholarship or grant.

The bottom section of Table 5 shows parents' anticipated funding sources for students with the strongest academic credentials. Here we see clear Black-White differences in parents' plans for college funding and, in particular, distinct patterns of college funding for highlyqualified Black girls. Parents of Black girls are considerably less likely than others to anticipate paying for college with their own earnings or savings — with a predicted probability of only .54 . The rest of the table gives some clues as to how parents of highly-qualified Black girls plan to make up for their lack of parental funding. Compared to parents of White boys, parents of Black girls are more likely to anticipate scholarships $(p<.001$; as are parents of Black boys, $p<.01)$. We also find that parents of highly-qualified Black girls are more likely than parents of White boys to anticipate use of a private loan in the parent's name $(p<.01)$. This is a troubling pattern, considering that private loans tend to have much higher interest rates than government-backed

11 The underlying regressions for Table 5 are shown in Appendix E in the online supplement. 
Table 5. Parents' Anticipated Funding Sources - by Academic Probability of Enrolling in College

\begin{tabular}{|c|c|c|c|c|}
\hline & $\begin{array}{l}\text { White } \\
\text { Boys }\end{array}$ & $\begin{array}{l}\text { White } \\
\text { Girls }\end{array}$ & $\begin{array}{c}\text { Black } \\
\text { Boys } \\
\end{array}$ & $\begin{array}{c}\text { Black } \\
\text { Girls } \\
\end{array}$ \\
\hline \multicolumn{5}{|c|}{30 Academic Probability of Enrollment } \\
\hline Parent's earnings/savings & .39 & .38 & .32 & .34 \\
\hline Student's earnings/savings & .38 & .40 & .38 & .35 \\
\hline Scholarships/grants & .63 & $.71 * \dagger$ & $.74 *$ & $.76^{*}$ \\
\hline Federal or state loans & .62 & .67 & .68 & $.74 *$ \\
\hline Private loan in student's name & .25 & .21 & .26 & .34 \\
\hline Private loan in parent's name & .32 & .27 & .29 & .29 \\
\hline \multicolumn{5}{|c|}{.70 Academic Probability of Enrollment } \\
\hline Parent's earnings/savings & .58 & .56 & $.48^{*}$ & $.46^{*}$ \\
\hline Student's earnings/savings & .39 & .40 & $.28^{*}$ & $.31 *$ \\
\hline Scholarships/grants & .75 & $.80 * \dagger$ & $.86^{*}$ & $.88^{*}$ \\
\hline Federal or state loans & .61 & $.64 * \dagger$ & $.69^{*}$ & .67 \\
\hline Private loan in student's name & .25 & .25 & .27 & .25 \\
\hline Private loan in parent's name & .28 & .29 & .33 & $.37 *$ \\
\hline \multicolumn{5}{|c|}{.95 Academic Probability of Enrollment } \\
\hline Parent's earnings/savings & .69 & .67 & .58 & $.54^{*}$ \\
\hline Student's earnings/savings & .39 & .40 & $.23 *$ & $.28 *$ \\
\hline Scholarships/grants & .82 & .84 & $.91 *$ & $.92 *$ \\
\hline Federal or state loans & .60 & .62 & .69 & .62 \\
\hline Private loan in student's name & .25 & .28 & .27 & .20 \\
\hline Private loan in parent's name & .27 & .31 & .36 & $.42 *$ \\
\hline
\end{tabular}

Source: High School Longitudinal Study of 2009.

Note: Logistic regressions; predicted probabilities reported. Models include control for type of college the respondent parent anticipates the child will attend in the fall (if any). Sample sizes are: 3,833 (parent's earnings/savings); 3,836 (student's earnings/savings); 3,833

(scholarships/grants); 3,834 (federal or state loans); 3,831 (private loan in student's name); 3,837 (private loan in parent's name).

$* p<.05$ for comparison of race/gender group to white boys; $\uparrow p<.05$ for comparison between boys and girls within race groups. More detailed $p$-values are included in the main text where applicable.

loans, and cost much more over the life of repayment (Consumer Financial Protection Bureau 2012). Overall, then, parents of highly-qualified Black girls are in the unique situation of having little earnings or savings to contribute for college. As a consequence of their lack of savings, these parents may turn to high-cost loans - a situation that may contribute to their own household's economic insecurity, as well as threaten their ability to assist their daughters financially in later years. 


\section{CONCLUSION}

By all accounts, paying for college is harder than it used to be. A growing body of research has demonstrated inequalities, particularly by race, in educational debt's impacts on long-run economic returns to college completion. Yet, less is known about parental college savings among recent cohorts of students, particularly using an intersectional framework.

Drawing on theories of parental investment, as well as research that points to persistent race and gender inequalities in economic resources and educational attainment, this article has assessed how parental college savings differs across race-gender groups. We used models that accounted for students' chances of college enrollment, considered separately by economic/family factors and academic credentials, to parse out race and gender differences in savings across these spectrums. The analyses pointed to stark differences in parental college savings between White boys, White girls, Black boys, and Black girls, as well as differences in the funding sources parents anticipate using to supplement their savings.

Perhaps the most striking patterns we find pertain to Black girls - and in particular, a distinct lack of parental college savings for Black girls with the strongest academic credentials. For White boys, White girls, and Black boys, we find a positive relationship between students' academic credentials and parental college savings. But for Black girls, parental college savings is virtually unresponsive to their academic qualifications. To investigate why this happens, we compared economic resources across race-gender groups for students with different academic profiles. These analyses suggest that highly-qualified Black students, and especially highlyqualified Black girls, come from families that are considerably less well-off than their White peers. Because most parents generally save in accordance with their ability to save, highly- 
qualified Black girls may end up with less savings by virtue of coming from relatively disadvantaged families.

This finding is consistent with prior research showing that Black girls are particularly resilient when it comes to academics, as they tend to enroll in and complete college even in the face of challenging economic circumstances (DiPrete and Buchmann 2013). We show that, as a potential consequences of Black girls over-indexing in terms of academic performance, Black girls may enroll in college with little parental savings to draw on—even if they have among the strongest academic credentials. This pattern underscores the idea that college funding is a mechanism through which higher education reproduces inequalities on account of race, gender, and class. Families of high-achieving Black girls are positioned to save relatively little, and to take on loans that are relatively high-risk, thus resulting in funding schemas that disadvantage Black girls and their families across generations. Although Black girls tend to over-index in terms of academic performance, our findings demonstrate that Black girls face continued challenges in achieving economic mobility through higher education.

Other (unmeasured) factors are likely to play a role in this story as well. Although we find clear economic differences between highly-qualified Black girls and those in other racegender groups, there may be other explanations for these distinct patterns of savings among parents of Black girls. This is not just a race effect, as we see key differences between parents of Black girls and boys; and this is not just a gender effect, as we see key differences between parents of Black girls and White girls. Rather, parental college savings is an intersectional issue at its core, and thus it requires intersectional explanations. It may be that parents of Black girls are more optimistic than other parents about their child's ability to receive a sizeable college scholarship - large enough to cover all or nearly all of their child's tuition and fees. We find that 
parents of highly-qualified Black girls and boys are equally likely to expect to pay for at least part of college with a grant or scholarship, but the size of the expected grant might differ (which we cannot assess with the HSLS data). Future research also can assess the extent to which family configuration (e.g., the effect of having brothers; Powell and Steelman 1989) explains Black girls' savings disadvantage (which, again, we are unable to assess with HSLS). All of this is to say that other factors are likely driving at least part of this lack of college savings among highachieving Black girls, and additional work is needed to shed light on this issue.

Our data do, however, make clear the long-term economic implications for parents of highly-qualified Black girls. To counter the lack of earnings or savings earmarked for their children's college education, these parents are more likely than those in other race-gender groups to anticipate using a private loan in their name. Private loans tend to have higher interest rates and less forgiving repayment schedules than government-backed loans, and thus they are considered a risky financial tool. This may make parents of Black girls vulnerable to economic insecurity in the long run. Besides their parents, these patterns also have negative implications for the financial circumstances of Black girls themselves, as well as their families, should they choose to form them (although research shows that debt and other financial obligations may delay young women's marriage and fertility; Addo 2014; Nau, Dwyer, and Hodson 2015). If parents of highly-qualified Black girls are using their resources to service these private loans, then their children stand to benefit even less from any subsequent potential intergenerational wealth transfers or gifts. Of course, research consistently shows that, when attempting to make these types of transfers, Blacks start from a much smaller pool than otherwise economically similar Whites to begin with (Darity et al. 2018; Herring and Henderson 2016; Killewald and 
Bryan 2018). For these reasons, the racially unequal economic constraints that prevent parents from saving for college may have economic implications that affect multiple generations.

In addition, we find that among those with few economic resources, Black parents tend to make greater investments in their children's college education than White parents. This pattern holds for both boys and girls, and echoes research on racial differences in parental college savings using earlier cohorts of students. Prior studies show that Black parents invest just as much (if not more) in college than White parents once background characteristics are controlled for (Steelman and Powell 1993), and our findings update this research by showing that this effect is concentrated among less advantaged families. At the top of the economic distribution, we find a clear savings advantage for Whites, likely driven by high-income Whites having greater average net worth than similarly high-income Blacks (Darity et al. 2018; Smith 1995). Our estimates are likely conservative here, given that the HSLS captures savings accounts that are specifically earmarked for higher education, but high-income Whites tend to have additional resources that can be used for college if needed (e.g., investments, home equity).

Our findings also have implications for debates about the "match" between students' academic credentials and the characteristics of the college they attend. This debate often centers on high-ability Black students who are potential beneficiaries of race-based affirmative action for admission to selective colleges. One side of this debate argues that Black students are better off attending colleges where most students are at or below their level of academic ability, and that those who shoot too high are "mismatched" to their institutions and may have negative experiences and outcomes, such as low grades or dropout. The balance of scholarly evidence refutes this claim, demonstrating that Black students benefit from attending selective institutions, 
in terms of outcomes such as college completion and eventual earnings (Alon and Tienda 2005; Bowen and Bok 2000; Massey et al. 2011).

Our results further inform this debate by calling attention to the interplay between institutional characteristics and intersectionally varying linkages between students' academic profiles and family economic circumstances. At a given level of high school academic successsuch as among high achievers who may have the option to attend a highly selective collegeBlack students, on average, come from much less affluent families than equally qualified White students. Thus, to the extent that elite colleges' institutional resources allow them to offer more financial aid and/or fewer loans (see, e.g., Rimer and Finder 2007), there may be multigenerational financial advantages for high-achieving Black students when they attend one of these elite colleges. Further, our intersectional lens has allowed us to demonstrate that highability Black girls, in particular, are the race-gender group that potentially stands to benefit most from institutional selectivity, to the extent selectivity is correlated with financial support.

Although the data provide clear evidence of parental college savings differences across race-gender groups, we should also emphasize two main data limitations. First, as we have noted previously, parental college savings is an imperfect measure of both parental economic resources and parents' expectations for their children's college attendance. Some parents might save less than others in similar economic circumstances because they work for a university where their child will receive a tuition benefit. Others might dial down their savings because they expect their child to receive a merit-based scholarship, or they anticipate receiving financial aid because they believe their child will attend a prestigious college and they will receive a generous aid package (although this is probably not common, given research showing that the population of highly-qualified low-income students applying to selective colleges is quite small; Hoxby and 
Avery 2012). Thus, while we consider parental college savings to be a reasonable proxy for these constructs, this measure is imperfect.

Second, the HSLS does not include information on parental net worth. This is an important omission, not only because net worth differs so dramatically across Black and White families, but also because wealth has been shown to affect college attendance net of income (Conley 2001). It is reasonable to assume that some aspects of wealth are captured in the dependent variable, as college savings accounts often include investments that are not classified as yearly income. But future research can incorporate data on other types of assets (not to mention other racial groups) to understand further how race and gender shape college funding and exposure to its multigenerational implications.

\section{RESEARCH ETHICS}

The High School Longitudinal Study of 2009 (HSLS:09) is a publicly available anonymized dataset.

\section{REFERENCES}

Addo, Fenaba R. 2014. "Debt, Cohabitation, and Marriage in Young Adulthood." Demography 51(5):1677-1701.

Addo, Fenaba R., Jason N. Houle, and Daniel Simon. 2016. "Young, Black, and (Still) in the Red: Parental Wealth, Race, and Student Loan Debt." Race and Social Problems 8:6476.

Alon, Sigal and Marta Tienda. 2005. "Assessing the 'Mismatch' Hypothesis: Differences in College Graduation Rates by Institutional Selectivity." Sociology of Education 78:294315.

Bassok, Daphna, Jenna E. Finch, RaeHyuck Lee, Sean F. Reardon, and Jane Waldfogel. 2016. "Socioeconomic Gaps in Early Childhood Experiences." AERA Open 2(3):1-22.

Becker, Gary. 1964. Human Capital. New York: National Bureau of Economic Research. 
Bowen, William G. and Derek Bok. 2000. The Shape of the River: Long-Term Consequences of Considering Race in College and University Admissions. Princeton, NJ: Princeton University Press.

Brand, Jennie E. and Yu Xie. 2010. "Who Benefits Most from College? Evidence for Negative Selection in Heterogeneous Economic Returns to Higher Education." American Sociological Review 75:273-302.

Buchmann, Claudia and Thomas A. DiPrete. 2006. "The Growing Female Advantage in College Completion: The Role of Family Background and Academic Achievement." American Sociological Review 71:515-41.

Bumpus, John P., Zimife Umeh, and Angel L. Harris. 2020. “Social Class and Educational Attainment: Do Blacks Benefit Less from Increases in Parents' Social Class Status?” Sociology of Race and Ethnicity 6(2):223-41.

Carbonaro, William, Brandy J. Ellison, and Elizabeth Covay. 2011. "Gender Inequalities in the College Pipeline." Social Science Research 40:120-35.

Carnevale, Anthony P. and Jeff Strohl. 2013. Separate and Unequal: How Higher Education Reinforces the Intergenerational Reproduction of White Racial Privilege. Washington, DC: Center on Education and the Workforce.

Charles, Camille Z., Vincent J. Roscigno, and Kimberly C. Torres. 2007. "Racial Inequality and College Attendance: The Mediating Role of Parental Investments." Social Science Research 36:329-52.

Collins, Patricia Hill. 1990. Black Feminist Thought. Boston: Unwin Hyman.

Conley, Dalton. 2001. "Capital for College: Parental Assets and Postsecondary Schooling." Sociology of Education 74:59-72.

Consumer Financial Protection Bureau. 2012. Private Student Loans. Available: https:// files.consumerfinance.gov/f/201207_cfpb_Reports_Private-Student-Loans.pdf.

Crenshaw, Kimberlé. 1989. "Demarginalizing the Intersection of Race and Sex." University of Chicago Legal Forum 1989:139-67.

Crenshaw, Kimberlé. 1991. "Mapping the Margins.” Stanford Law Review 43:1241-99.

Darity, William et al. 2018. What We Get Wrong About Closing the Racial Wealth Gap. Durham, NC.

DiPrete, Thomas A. and Claudia Buchmann. 2013. The Rise of Women: The Growing Gender Gap in Education and What It Means for American Schools. New York: Russell Sage. 
Downey, Douglas B. 1995. "When Bigger Is Not Better: Family Size, Parental Resources, and Children's Educational Performance." American Sociological Review 60:746-61.

Dwyer, Rachel E. 2018. "Credit, Debt, and Inequality.” Annual Review of Sociology 44:237-61.

Dwyer, Rachel E., Randy Hodson, and Laura McCloud. 2013. "Gender, Debt, and Dropping Out of College." Gender \& Society 27:30-55.

Dwyer, Rachel E., Laura McCloud, and Randy Hodson. 2012. "Debt and Graduation from American Universities." Social Forces 90:1133-55.

Federal Reserve Bank of New York. 2018. Quarterly Report on Household Debt and Credit. Available: https://www.newyorkfed.org/medialibrary/interactives/householdcredit/ data/pdf/hhdc_2018q4.pdf.

Gibbs, Benjamin G., Joseph Workman, and Douglas B. Downey. 2016. “The (Conditional) Resource Dilution Model: State- and Community-Level Modifications." Demography $53: 723-48$.

Hamilton, Laura T. 2013. "More Is More or More Is Less? Parental Financial Investments during College." American Sociological Review 78:70-95.

Hamilton, Laura T. 2016. Parenting to a Degree: How Family Matters for College Women's Success. Chicago: University of Chicago Press.

Herring, Cedric and Loren Henderson. 2016. "Wealth Inequality in Black and White: Cultural and Structural Sources of the Racial Wealth Gap." Race and Social Problems 8:4-17.

Houle, Jason N. 2014a. "A Generation Indebted: Young Adult Debt across Three Cohorts." Social Problems 61:448-65.

Houle, Jason N. 2014b. "Disparities in Debt: Parents' Socioeconomic Resources and Young Adult Student Loan Debt.” Sociology of Education 87:53-69.

Houle, Jason N. and Fenaba R. Addo. 2019. "Racial Disparities in Student Debt and the Reproduction of the Fragile Black Middle Class." Sociology of Race and Ethnicity 5(4):562-77.

Houle, Jason N. and Cody Warner. 2017. "Into the Red and Back to the Nest? Student Debt, College Completion, and Returning to the Parental Home among Young Adults." Sociology of Education 90(1):89-108.

Hoxby, Caroline M. and Christopher Avery. 2012. "The Missing 'One-Offs': The Hidden Supply of High-Achieving, Low Income Students." National Bureau of Economic Research. 
Iloh, Constance and Ivory A. Toldson. 2013. "Black Students in 21st Century Higher Education: A Closer Look at For-Profit and Community Colleges." The Journal of Negro Education 82:205-12.

Jackson, Brandon A. and John R. Reynolds. 2013. "The Price of Opportunity: Race, Student Loan Debt, and College Achievement." Sociological Inquiry 83:335-68.

Killewald, Alexandra and Brielle Bryan. 2018. "Falling Behind: The Role of Inter- and Intragenerational Processes in Widening Racial and Ethnic Wealth Gaps through Early and Middle Adulthood." Social Forces 97:705-40.

Massey, Douglas S., Camille Z. Charles, Garvey F. Lundy, and Mary J. Fischer. 2011. The Source of the River: The Social Origins of Freshmen at America's Selective Colleges and Universities. Princeton, NJ: Princeton University Press.

McCabe, Janice and Brandon A. Jackson. 2016. "Pathways to Financing College: Race and Class in Students' Narratives of Paying for School." Social Currents 3:367-85.

McCall, Leslie. 2005. “The Complexity of Intersectionality.” Signs 30(3):1771-1800.

McDaniel, Anne, Thomas A. DiPrete, Claudia Buchmann, and Uri Shwed. 2011. "The Black Gender Gap in Educational Attainment: Historical Trends and Racial Comparisons." Demography 48:889-914.

Miller, Kevin. 2019. Deeper in Debt: Women and Student Loans. Washington, DC: American Association of University Women.

Nau, Michael, Rachel E. Dwyer, and Randy Hodson. 2015. "Can't Afford a Baby? Debt and Young Americans.” Research in Social Stratification and Mobility 42:114-22.

Powell, Brian and Lala Carr Steelman. 1989. "The Liability of Having Brothers: Paying for College and the Sex Composition of the Family." Sociology of Education 62:134-47.

Quadlin, Natasha Yurk. 2015. "When Children Affect Parents: Children's Academic Performance and Parental Investment." Social Science Research 51:672-85.

Quadlin, Natasha. 2017. "Funding Sources, Family Income, and Fields of Study in College." Social Forces 96:91-120.

Quadlin, Natasha. 2019. "Sibling Achievement, Sibling Gender, and Beliefs about Parental Investment: Evidence from a National Survey Experiment." Social Forces 97:1603-30.

Quadlin, Natasha Yurk and Daniel Rudel. 2015. "Responsibility or Liability? Student Loan Debt and Time Use in College." Social Forces 94:589-614. 
Raley, Sara and Suzanne Bianchi. 2006. "Sons, Daughters, and Family Processes: Does Gender of Children Matter?” Annual Review of Sociology 32:401-21.

Rauscher, Emily. 2016. "Passing It On: Parent-to-Adult Child Financial Transfers for School and Socioeconomic Attainment." RSF: The Russell Sage Foundation Journal of the Social Sciences 2:172-96.

Reardon, Sean F. 2011. "The Widening Academic Achievement Gap Between the Rich and the Poor: New Evidence and Possible Explanations." Pp. 91-116 in Whither Opportunity? Rising Inequality, Schools, and Children's Life Chances, edited by G. J. Duncan and R. J. Murnane. New York: Russell Sage.

Ridgeway, Cecilia L. 2011. Framed by Gender: How Gender Inequality Persists in the Modern World. New York: Oxford University Press.

Rimer, Sara and Alan Finder. 2007. "Harvard Steps up Financial Aid." The New York Times.

Scott-Clayton, Judith and Jing Li. 2016. Black-White Disparity in Student Loan Debt More Than Triples after Graduation. Washington, DC: Brookings Institution.

Sewell, William H., Archibald O. Haller, and Alejandro Portes. 1969. "The Educational and Early Occupational Attainment Process." American Sociological Review 34:82-92.

Smith, James P. 1995. "Racial and Ethnic Differences in Wealth in the Health and Retirement Study." Journal of Human Resources 30:S158-83.

Snyder, Thomas D., Cristobal de Brey, and Sally A. Dillow. 2019. Digest of Education Statistics 2017. Washington, DC: National Center for Education Statistics.

Steelman, Lala Carr and Brian Powell. 1991. "Sponsoring the Next Generation: Parental Willingness to Pay for Higher Education.” American Journal of Sociology 96:1505-29.

Steelman, Lala Carr and Brian Powell. 1993. "Doing the Right Thing: Race and Parental Locus of Responsibility for Funding College." Sociology of Education 66:223-44.

Steelman, Lala Carr, Brian Powell, Regina Werum, and Scott Carter. 2002. "Reconsidering the Effects of Sibling Configuration: Recent Advances and Challenges." Annual Review of Sociology 28:243-69.

Turley, Ruth N. López and Matthew Desmond. 2011. "Contributions to College Costs by Married, Divorced, and Remarried Parents.” Journal of Family Issues 32:767-90.

Wingfield, Adia H. 2009. "Racializing the Glass Escalator." Gender \& Society 23(1):5-26.

Wilson, William Julius. 1978. “The Declining Significance of Race.” Society 15:56-62. 
Wilson, William Julius. 2011. “The Declining Significance of Race': Revisited \& Revised.” Daedalus 140:55-69.

Wilson, William Julius. 2012. The Truly Disadvantaged: The Inner City, the Underclass, and Public Policy. 2nd edition. Chicago: University of Chicago Press.

\section{AUTHOR BIOGRAPHIES}

Natasha Quadlin is Assistant Professor of Sociology at the University of California, Los Angeles. Her research focuses on social inequality in the contemporary U.S., with an emphasis on access and returns to education. Current projects examine perceptions of responsibility for college costs, income inequality among college graduates, and public attitudes toward gender and sexuality.

Jordan A. Conwell is an Assistant Professor of Sociology at the University of WisconsinMadison. His research focuses on trends and consequences of racial, social class, and gender inequality in schooling, with a particular emphasis on how these patterns are related to families and their finances. 


\section{Appendix A. Comparison between Variables used in Brand and Xie (2010) and This Paper Variables used in Brand and Xie (2010) \\ Variables available in HSLS:09}

\section{Economic/family factors}

Family income

NLSY: Total net family income

WLS: Parents' income

Mother's and father's highest level of education

Intact family

Number of siblings

Residence

NLSY: Whether R lived in an SMSA

WLS: Whether R's high school was within 15

miles of a college or university

Jewish

\section{Academic factors}

Class rank (in WLS only)

Mental ability

NLSY: ASVAB

WLS: Henmon-Nelson Test of Mental Ability

College prep

NLSY: Whether R was enrolled in college-

preparatory curriculum

WLS: Whether R had completed the

requirements for UW-Madison

Teachers' encouragement (in WLS only)

Parents' encouragement (in WLS only)

Friends' college plans
N/A

Family income

Highest level of education completed by either parent

Whether the $\mathrm{R}$ parent is married or partnered

Number of siblings

Whether R's high school is located in an urban area

N/A

R's score on an NCES-administered math test

Whether R took at least one AP course
N/A

N/A

Whether R believes "all" of his or her friends plan to attend a four-year college

Note: Brand and Xie use data from both the National Longitudinal Survey of Youth-1979 Cohort (NLSY) and the Wisconsin Longitudinal Study (WLS). Differences in measurement between the NLSY and WLS datasets are noted in the table. 
Appendix B. Effects of Race, Gender, and Predicted Probability of Enrolling in College on Parental College Savings

\begin{tabular}{|c|c|c|c|c|}
\hline & \multicolumn{2}{|c|}{$\begin{array}{l}\text { Probability computed using } \\
\text { Economic/Family Factors }\end{array}$} & \multicolumn{2}{|c|}{$\begin{array}{c}\text { Probability computed using } \\
\text { Academic Factors }\end{array}$} \\
\hline & $\begin{array}{c}\text { Saved } \\
\text { anything? } \\
(1)\end{array}$ & $\begin{array}{c}\text { Amount saved } \\
\text { (among savers) } \\
\text { (2) }\end{array}$ & $\begin{array}{c}\text { Saved } \\
\text { anything? } \\
(3)\end{array}$ & $\begin{array}{c}\text { Amount saved } \\
\text { (among savers) } \\
\text { (4) }\end{array}$ \\
\hline Female & $\begin{array}{l}-0.22 \\
(0.45)\end{array}$ & $\begin{array}{c}5.15 \\
(7.19)\end{array}$ & $\begin{array}{l}-0.39 \\
(0.33)\end{array}$ & $\begin{array}{l}-1.44 \\
(5.52)\end{array}$ \\
\hline Black & $\begin{array}{c}0.53 \\
(0.65)\end{array}$ & $\begin{array}{l}30.32 * * * \\
(6.84)\end{array}$ & $\begin{array}{l}-0.47 \\
(0.67)\end{array}$ & $\begin{array}{l}-8.70 \\
(4.97)\end{array}$ \\
\hline Female*Black & $\begin{array}{l}1.19 \\
(0.85)\end{array}$ & $\begin{array}{r}-14.06 \\
(9.05)\end{array}$ & $\begin{array}{c}1.21 \\
(0.89)\end{array}$ & $\begin{array}{l}12.18 \\
(7.54)\end{array}$ \\
\hline Prob of enrollment & $\begin{array}{l}4.27^{* * *} \\
(0.45)\end{array}$ & $\begin{array}{l}71.26^{* * *} \\
(6.97)\end{array}$ & $\begin{array}{l}1.72^{* * *} \\
(0.33)\end{array}$ & $\begin{array}{l}27.79^{* * *} \\
(5.53)\end{array}$ \\
\hline Female*Prob & $\begin{array}{c}0.21 \\
(0.62)\end{array}$ & $\begin{array}{r}-10.69 \\
(9.96)\end{array}$ & $\begin{array}{c}0.33 \\
(0.47)\end{array}$ & $\begin{array}{l}-3.37 \\
(7.68)\end{array}$ \\
\hline Black*Prob & $\begin{array}{l}-1.34 \\
(1.00)\end{array}$ & $\begin{array}{l}-54.20^{* * *} \\
(10.65)\end{array}$ & $\begin{array}{l}-0.35 \\
(1.06)\end{array}$ & $\begin{array}{l}-1.44 \\
(9.04)\end{array}$ \\
\hline Female*Black*Prob & $\begin{array}{l}-1.77 \\
(1.36)\end{array}$ & $\begin{array}{c}24.79 \\
(14.09)\end{array}$ & $\begin{array}{l}-1.58 \\
(1.40)\end{array}$ & $\begin{array}{l}-18.03 \\
(12.36)\end{array}$ \\
\hline Parents anticipate: & & & & \\
\hline Occupational training & $\begin{array}{c}0.63^{*} \\
(0.27)\end{array}$ & $\begin{array}{l}-2.29 \\
(3.58)\end{array}$ & $\begin{array}{l}0.69 * * \\
(0.26)\end{array}$ & $\begin{array}{c}0.11 \\
(3.63)\end{array}$ \\
\hline Two-year & $\begin{array}{c}0.47 \\
(0.33)\end{array}$ & $\begin{array}{c}1.10 \\
(6.58)\end{array}$ & $\begin{array}{c}0.58 \\
(0.32)\end{array}$ & $\begin{array}{c}2.89 \\
(5.85)\end{array}$ \\
\hline Four-year unspecified & $\begin{array}{l}0.92 * * * \\
(0.23)\end{array}$ & $\begin{array}{l}1.45 \\
(3.26)\end{array}$ & $\begin{array}{l}1.28^{* * *} \\
(0.21)\end{array}$ & $\begin{array}{c}7.59^{*} \\
(3.54)\end{array}$ \\
\hline Public in-state & $\begin{array}{l}0.89^{* * *} \\
(0.20)\end{array}$ & $\begin{array}{l}-3.82 \\
(2.75)\end{array}$ & $\begin{array}{l}1.24 * * * \\
(0.18)\end{array}$ & $\begin{array}{c}3.06 \\
(3.07)\end{array}$ \\
\hline Public out-of-state & $\begin{array}{l}1.19^{* * *} \\
(0.25)\end{array}$ & $\begin{array}{c}0.44 \\
(3.50)\end{array}$ & $\begin{array}{l}1.55^{* * *} \\
(0.25)\end{array}$ & $\begin{array}{c}8.56^{*} \\
(3.80)\end{array}$ \\
\hline Private & $\begin{array}{l}1.01 * * * \\
(0.23)\end{array}$ & $\begin{array}{l}9.56^{* *} \\
(3.35)\end{array}$ & $\begin{array}{l}1.42^{* * *} \\
(0.22)\end{array}$ & $\begin{array}{l}16.94 * * * \\
(3.65)\end{array}$ \\
\hline Constant & $\begin{array}{l}-3.55^{* * *} \\
(0.36)\end{array}$ & $\begin{array}{c}-28.53 * * * \\
(5.10) \\
\end{array}$ & $\begin{array}{l}-2.03 * * * \\
(0.28) \\
\end{array}$ & $\begin{array}{l}-0.92 \\
(4.38) \\
\end{array}$ \\
\hline$N / n$ & 3,895 & 2,129 & 3,895 & 2,129 \\
\hline
\end{tabular}

Source: High School Longitudinal Study of 2009.

Note: These are the underlying regressions for Figures 2 and 3 in the main text. Logistic regressions (Models 1 and 3) and OLS regressions (Models 2 and 4); coefficients reported. Robust standard errors in parentheses. Analyses are weighted. Omitted categories are male, white, parents haven't thought about type of college child will enroll in.

$* p<.05,{ }^{* *} p<.01,{ }^{* * *} p<.001$ (two-tailed tests) 
Appendix C. Amount Parents Have Saved for Child's College Education, $n=2,129$ - Natural Log of Parental College Savings (A) - Student's Probability of Enrollment Estimated with Economic/Family Factors

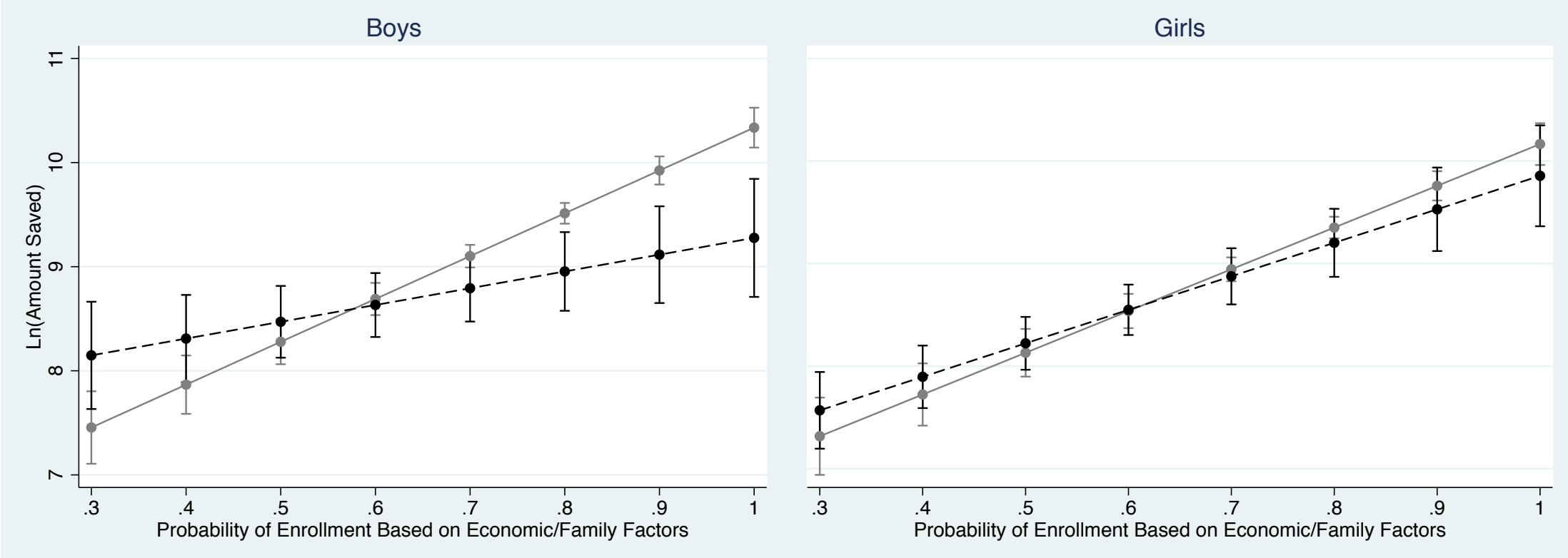

(B) - Student's Probability of Enrollment Estimated with Academic Factors

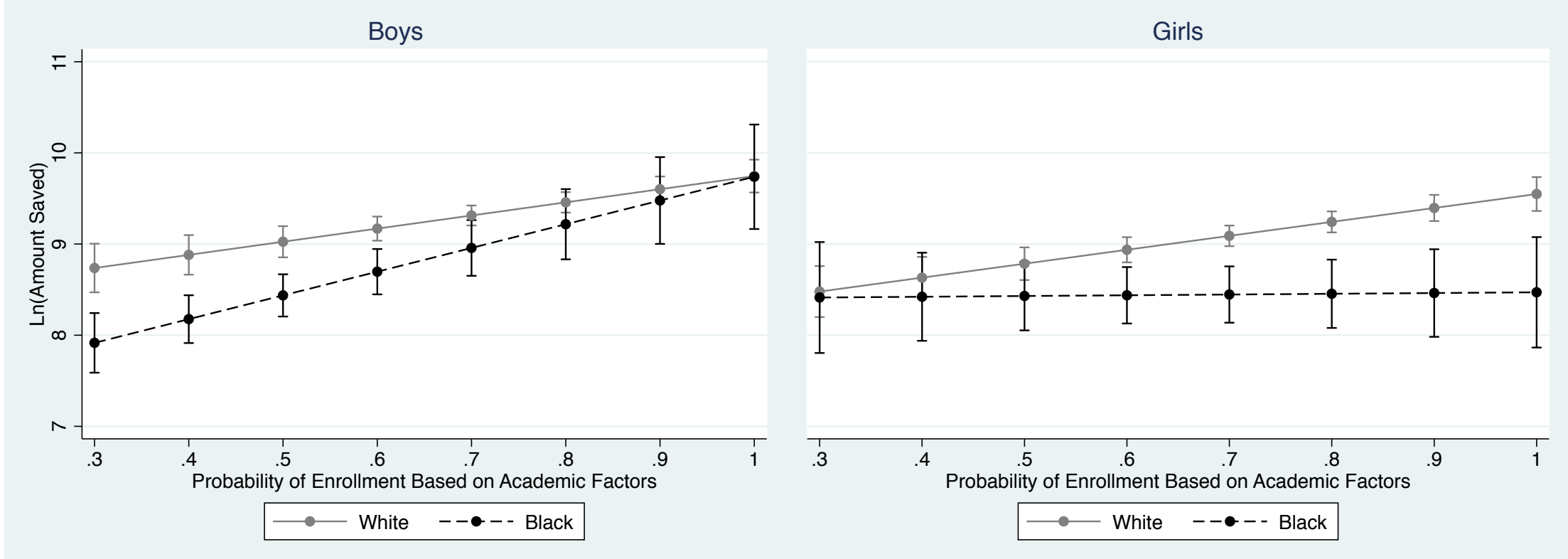

Source: High School Longitudinal Study of 2009. Note: Models include control for type of college the respondent parent anticipates the child will attend in the fall (if any). 
Appendix D. Effects of Race, Gender, and Probability of Enrollment (as Estimated by Economic/Family Factors) on Anticipated Funding Sources

\begin{tabular}{|c|c|c|c|c|c|c|}
\hline$x=$ & $\begin{array}{l}\text { Parent's } \\
\text { earnings/ } \\
\text { savings } \\
\text { (1) }\end{array}$ & $\begin{array}{c}\text { Student's } \\
\text { earnings/ } \\
\text { savings } \\
(2)\end{array}$ & $\begin{array}{c}\text { Scholarships } \\
\text { or grants } \\
(3) \\
\end{array}$ & $\begin{array}{c}\text { Federal or } \\
\text { state loans } \\
(4) \\
\end{array}$ & $\begin{array}{c}\text { Private loan } \\
\text { in student's } \\
\text { name } \\
(5)\end{array}$ & $\begin{array}{c}\text { Private loan } \\
\text { in parent's } \\
\text { name } \\
(6)\end{array}$ \\
\hline \multirow[t]{2}{*}{ Female } & 0.70 & 0.31 & 0.48 & -0.28 & -0.13 & -0.26 \\
\hline & $(0.49)$ & $(0.37)$ & $(0.45)$ & $(0.41)$ & $(0.41)$ & $(0.38)$ \\
\hline \multirow[t]{2}{*}{ Black } & $2.62 * *$ & $1.43 *$ & -0.54 & -0.72 & 0.07 & 1.18 \\
\hline & $(0.84)$ & $(0.62)$ & $(0.73)$ & $(0.69)$ & $(0.72)$ & $(0.77)$ \\
\hline \multirow[t]{2}{*}{ Female*Black } & -1.79 & $-1.91 *$ & -0.26 & 0.50 & 0.79 & -0.55 \\
\hline & $(1.02)$ & $(0.82)$ & $(0.97)$ & $(0.88)$ & $(0.94)$ & $(0.97)$ \\
\hline \multirow[t]{2}{*}{ Prob of enrollment } & $5.00 * * *$ & -0.09 & -0.66 & $-1.24 * *$ & 0.29 & 0.76 \\
\hline & $(0.51)$ & $(0.38)$ & $(0.45)$ & $(0.42)$ & $(0.42)$ & $(0.40)$ \\
\hline \multirow[t]{2}{*}{ Female*Prob } & -0.92 & -0.23 & -0.29 & 0.73 & 0.41 & 0.46 \\
\hline & $(0.67)$ & $(0.51)$ & $(0.63)$ & $(0.56)$ & $(0.56)$ & $(0.53)$ \\
\hline \multirow[t]{2}{*}{ Black*Prob } & $-4.40 * * *$ & $-2.84 * *$ & 1.73 & 1.66 & 0.35 & -1.25 \\
\hline & $(1.32)$ & $(1.04)$ & $(1.22)$ & $(1.07)$ & $(1.12)$ & $(1.25)$ \\
\hline \multirow[t]{2}{*}{ Female*Black*Prob } & 2.68 & $2.80^{*}$ & 0.34 & -1.38 & -1.75 & 1.18 \\
\hline & $(1.61)$ & $(1.39)$ & $(1.65)$ & $(1.42)$ & $(1.52)$ & $(1.58)$ \\
\hline \multicolumn{7}{|l|}{ Parents anticipate: } \\
\hline \multirow[t]{2}{*}{ Occupational training } & 0.38 & $0.67 *$ & 0.37 & $0.69 * *$ & 0.29 & 0.25 \\
\hline & $(0.33)$ & $(0.28)$ & $(0.26)$ & $(0.26)$ & $(0.30)$ & $(0.31)$ \\
\hline \multirow[t]{2}{*}{ Two-year } & 0.13 & $0.72 *$ & 0.37 & 0.60 & 0.23 & 0.08 \\
\hline & $(0.39)$ & $(0.35)$ & $(0.33)$ & $(0.32)$ & $(0.38)$ & $(0.40)$ \\
\hline \multirow[t]{2}{*}{ Four-year unspec. } & 0.46 & $0.59^{*}$ & $0.68 * *$ & $0.85 * * *$ & 0.45 & 0.24 \\
\hline & $(0.29)$ & $(0.24)$ & $(0.24)$ & $(0.23)$ & $(0.27)$ & $(0.28)$ \\
\hline \multirow[t]{2}{*}{ Public in-state } & $0.67 *$ & $0.70 * *$ & $0.81 * * *$ & $0.87 * * *$ & 0.16 & 0.31 \\
\hline & $(0.26)$ & $(0.21)$ & $(0.20)$ & $(0.20)$ & $(0.24)$ & $(0.26)$ \\
\hline \multirow[t]{2}{*}{ Public out-of-state } & $0.73^{*}$ & $0.73 * *$ & $1.11 * * *$ & $1.00 * * *$ & 0.16 & 0.32 \\
\hline & $(0.35)$ & $(0.26)$ & $(0.28)$ & $(0.26)$ & $(0.29)$ & $(0.33)$ \\
\hline \multirow[t]{2}{*}{ Private } & $0.87 * *$ & $0.78 * *$ & $1.31 * * *$ & $0.66 * *$ & 0.48 & 0.32 \\
\hline & $(0.29)$ & $(0.24)$ & $(0.26)$ & $(0.23)$ & $(0.26)$ & $(0.28)$ \\
\hline \multirow[t]{2}{*}{ Constant } & $-3.84 * * *$ & $-1.04 * * *$ & $0.67 *$ & 0.57 & $-1.58 * * *$ & $-1.73 * * *$ \\
\hline & $(0.43)$ & $(0.30)$ & $(0.33)$ & $(0.32)$ & $(0.33)$ & $(0.33)$ \\
\hline$n$ & 3,833 & 3,836 & 3,833 & 3,834 & 3,831 & 3,837 \\
\hline
\end{tabular}

Source: High School Longitudinal Study of 2009.

Note: These are the underlying regressions for Table 4 in the main text. Logistic regressions; coefficients reported. Robust standard errors in parentheses. Analyses are weighted. Omitted categories are male, white, parents haven't thought about type of college child will enroll in.

$* p<.05, * * p<.01, * * * p<.001$ (two-tailed tests) 
Appendix E. Effects of Race, Gender, and Probability of Enrollment (as Estimated by Academic Factors) on Anticipated Funding Sources

\begin{tabular}{|c|c|c|c|c|c|c|}
\hline 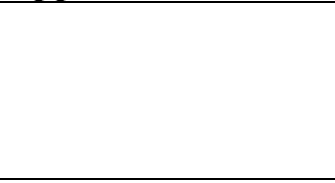 & $\begin{array}{l}\text { Parent's } \\
\text { earnings/ } \\
\text { savings } \\
\text { (1) }\end{array}$ & $\begin{array}{l}\text { Student's } \\
\text { earnings/ } \\
\text { savings } \\
(2) \\
\end{array}$ & $\begin{array}{c}\text { Scholarships } \\
\text { or grants } \\
\text { (3) } \\
\end{array}$ & $\begin{array}{c}\text { Federal or } \\
\text { state loans } \\
\\
(4) \\
\end{array}$ & $\begin{array}{c}\text { Private loan } \\
\text { in student's } \\
\text { name } \\
(5)\end{array}$ & $\begin{array}{c}\text { Private loan } \\
\text { in parent's } \\
\text { name } \\
(6)\end{array}$ \\
\hline \multirow[t]{2}{*}{ Female } & 0.13 & 0.04 & 0.32 & 0.32 & -0.39 & -0.34 \\
\hline & $(0.34)$ & $(0.32)$ & $(0.36)$ & $(0.34)$ & $(0.36)$ & $(0.34)$ \\
\hline \multirow[t]{2}{*}{ Black } & -0.14 & 0.83 & 0.15 & -0.08 & 1.02 & 0.39 \\
\hline & $(0.70)$ & $(0.67)$ & $(0.70)$ & $(0.71)$ & $(0.72)$ & $(0.65)$ \\
\hline \multirow[t]{2}{*}{ Female*Black } & 0.53 & -0.76 & 0.24 & 0.71 & 0.02 & -0.09 \\
\hline & $(0.91)$ & $(0.86)$ & $(0.93)$ & $(0.92)$ & $(0.91)$ & $(0.88)$ \\
\hline \multirow{2}{*}{ Prob of enrollment } & $2.04 * * *$ & -0.17 & $1.25 * * *$ & -0.37 & -0.00 & -0.19 \\
\hline & $(0.35)$ & $(0.32)$ & $(0.36)$ & $(0.33)$ & $(0.35)$ & $(0.34)$ \\
\hline \multirow{2}{*}{ Female*Prob } & -0.24 & 0.16 & -0.03 & -0.11 & 0.77 & 0.55 \\
\hline & $(0.48)$ & $(0.45)$ & $(0.52)$ & $(0.48)$ & $(0.49)$ & $(0.47)$ \\
\hline \multirow[t]{2}{*}{ Black*Prob } & -0.25 & -1.61 & 1.01 & 0.72 & -1.62 & -0.04 \\
\hline & $(1.13)$ & $(1.10)$ & $(1.20)$ & $(1.16)$ & $(1.15)$ & $(1.07)$ \\
\hline \multirow[t]{2}{*}{ Female*Black*Prob } & -1.23 & 0.70 & -0.79 & -1.87 & 0.00 & 0.29 \\
\hline & $(1.45)$ & $(1.40)$ & $(1.63)$ & $(1.49)$ & $(1.46)$ & $(1.41)$ \\
\hline \multicolumn{7}{|l|}{ Parents anticipate: } \\
\hline \multirow[t]{2}{*}{ Occ. training } & 0.46 & $0.58 *$ & 0.47 & $0.71 * *$ & 0.27 & 0.26 \\
\hline & $(0.31)$ & $(0.26)$ & $(0.26)$ & $(0.26)$ & $(0.31)$ & $(0.31)$ \\
\hline \multirow[t]{2}{*}{ Two-year } & 0.24 & 0.65 & 0.44 & 0.56 & 0.25 & 0.09 \\
\hline & $(0.36)$ & $(0.33)$ & $(0.32)$ & $(0.32)$ & $(0.38)$ & $(0.39)$ \\
\hline \multirow[t]{2}{*}{ Four-year unspec. } & $0.81 * *$ & $0.52 *$ & 0.39 & $0.81 * * *$ & 0.52 & 0.36 \\
\hline & $(0.27)$ & $(0.23)$ & $(0.23)$ & $(0.23)$ & $(0.27)$ & $(0.29)$ \\
\hline \multirow[t]{2}{*}{ Public in-state } & $1.02 * * *$ & $0.63 * *$ & $0.65 * * *$ & $0.83 * * *$ & 0.21 & 0.42 \\
\hline & $(0.24)$ & $(0.20)$ & $(0.19)$ & $(0.19)$ & $(0.23)$ & $(0.26)$ \\
\hline \multirow[t]{2}{*}{ Public out-of-state } & $1.14 * * *$ & $0.69 * *$ & $0.90 * *$ & $0.94 * * *$ & 0.19 & 0.46 \\
\hline & $(0.32)$ & $(0.26)$ & $(0.28)$ & $(0.26)$ & $(0.30)$ & $(0.33)$ \\
\hline \multirow[t]{2}{*}{ Private } & $1.26 * * *$ & $0.72 * *$ & $0.94 * * *$ & $0.63 * *$ & $0.55^{*}$ & 0.48 \\
\hline & $(0.27)$ & $(0.23)$ & $(0.25)$ & $(0.22)$ & $(0.26)$ & $(0.28)$ \\
\hline \multirow[t]{2}{*}{ Constant } & $-2.03 * * *$ & $-0.92 * * *$ & -0.46 & -0.02 & $-1.41 * * *$ & $-1.16^{* * *}$ \\
\hline & $(0.31)$ & $(0.27)$ & $(0.28)$ & $(0.27)$ & $(0.31)$ & $(0.31)$ \\
\hline$n$ & 3,833 & 3,836 & 3,833 & 3,834 & 3,831 & 3,837 \\
\hline
\end{tabular}

Source: High School Longitudinal Study of 2009.

Note: These are the underlying regressions for Table 5 in the main text. Logistic regressions; coefficients reported. Robust standard errors in parentheses. Analyses are weighted. Omitted categories are male, white, parents haven't thought about type of college child will enroll in.

$* p<.05, * * p<.01, * * * p<.001$ (two-tailed tests) 